\section{The perceived suitability of management accounting information: a contingency based investigation}

Ewelina ZARZYCKA, University of Lodz, Poland, E-mail: ezarzycka@uni.lodz.pl

Justyna DOBROSZEK,

University of Lodz, Poland, E-mail: justyna.dobroszek@gmail.com

Cristina CIRCA, West University of Timişoara, Romania, E-mail: cristina.circa@e-uvt.ro

Alina Almăşan, West University of Timişoara, Romania, E-mail: alina.almasan@e-uvt.ro

\section{Albstract}

The current paper aims at testing the existence and the strength of the relationship between selected variables and the managers' assessment of the information provided by the management accounting system (MAS), based on a contingency approach. In order to achieve the objective of the paper, we employed the correlation analysis with the purpose of investigating the strength of the relationship between the assessments made by managers with respect to the suitability of the management accounting information and certain variables (the company profile, the manager profile and the operations of the management accounting department). In this context, we used the data collected from randomly selected managers active in companies located in two Central and Eastern European countries, i.e. Poland and Romania. We found moderate relationships to the assessed suitability of the MAS information only for two of the three variables: the manager profile - mainly with respect to the managed department, and the operations of the management accounting department - mainly with respect to the frequency of the meetings between the manager and the management accountant.

Keywords: Managers' perception, management accounting, contingency factors, correlations

JEL Classification: M10, M49

To cite this article:

Zazycka, E., Dobroszek, J., Circa, C. and Almăşan, A. (2017),

The perceived suitability of management accounting

information: a contingency based investigation, Audit Financiar, vol. XV, no. 3(147)/2017, pp. 395-417,

DOI: 10.20869/AUDITF/2017/147/395

To link to this article:

http://dx.doi.org/10.20869/AUDITF/2017/147/395

Received: 02.04.2017

Revised: 20.04.2017

Accepted: 21.04.2017 


\section{Introduction}

Though the managers' perception is widely debated in literature, whenever it comes to the usefulness of the information provided by the management accounting system (MAS), the topic still arouses interest. The review of the specific literature reveals a wide range of studies in this direction (Chenhall and Morris, 1986; Mendoza and Bescos, 2001; Pierce and O'Dea, 2003; Cheffi and Beldi, 2012). Yet, these studies highlight mainly the differences between the perception of information providers and that of information users, called forth by fundamentally different motivations and attitudes. What is not often encountered in the context, though it should, is a debate on the internal and external factors influencing the manner in which managers, as information users, assess the information delivered by the management accounting system.

Research in management accounting is often focused on issues like organizational systems and processes, information use, the behaviour of accountants and other users (Gupta and Govindarajan, 1991). Management accounting practices are analyzed at micro - and macro level (Granlund and Lukka, 1998), whereas the two levels refer to the scope and comprehensiveness of management accounting issues. The macro-level consists of concepts, ideas, techniques, system designs and the purpose of using MA information, while the micro-level refers to behavioural patterns and styles of the information use (Ahrenes, 1996), tasks, operations and actors of the management accounting system, i.e. management accountants as providers of management accounting information, and managers as users of management accounting (Granlund and Lukka, 1998).

There is a significant amount of research built on a contingency-based approach, examining factors like the external environment (Gordon and Miller, 1976; Merchant, 1990; Hartman, 2000; Haldma and Laats, 2002; Otley, 2016), the national culture (Hofstede, 1984; O'Connor, 1995), the technology (Otley, 2016; Haldma and Laats, 2002), the size of the company (Dropulic, 2013; Merchant, 1985; Sharma, 2002; Chenhall, 2007; Cadez and Guilding, 2008), or its strategy (Gupta and Govindarajan, 1984; Simons, 1987; Chenhall and Morris, 1986). All these analyses were performed in different contexts; still, there are few studies on contingency factors in developing countries and these mainly approach the influence of such factors on management accounting practices (Albu and Albu, 2012; Hopper et al., 2009; Jaruga and Ho, 2002; Haldma and Laats, 2002; Anderson and Lanen, 1999). The relationship between these variables and the managers' perception on the usefulness of information for the decision-making process hasn't been debated at all, to the best of our knowledge. In this context, the present paper expands the analysis and fills the literature gap by performing a vast study of the interdependence between several variables and the relevance of the information provided to managers by management accounting.

Starting from these premises, the objective of the current paper is to test the strength of the relationship between selected variables and the managers' assessment of the information provided by the management accounting system, based on a contingency approach. For this purpose, we relied on data collected from randomly selected companies located in Poland and Romania. More, the study includes a comparative analysis of the determining factors identified in the two countries.

Central and Eastern European countries are a proper field for testing managers' perception on the matter of interest, out of two reasons. First, the development of management accounting in this area started after completing the long period of a centrally planned economy. The 90 s were characterised by significant political and economic changes, with a major impact on the accounting system and further on the perception of the provided information. It is a consequence of the fact that, after a time in which decisions were made on a central level, the new economical background compelled companies to act independently and employ tools supporting an efficient business administration. Secondly, the interest of the managers for management accounting increased gradually as a consequence of the incentives provided first by the academia and then by the business environment itself. The academics included management accounting in their research concerns (Szychta, 2002; Haldma and Laats, 2002; Albu and Albu, 2012), and launched joint projects with the business environment. In the meantime, the local branches of multinational companies in former communist countries raised the awareness of managers with regard to the role played by management accounting information in decisionmaking. 
Both Poland and Romania are CEE countries that belong to the above-described context, yet exhibit relevant differences in the development of management accounting, with Poland being one step ahead. First of all, right after 1990, the accounting systems of the two countries were confronted with two different influences, coming from abroad: the influence of the German accounting system in Poland, respectively the influence of the French accounting system in Romania. Secondly, concerns over management accounting were raised much earlier in Poland, due to the involvement of the academia in this area even prior to the fall of communism. Thirdly, the Romanian accounting regulations created confusion among practitioners, by displacing their interest towards the delivery of information for external reporting (provided by financial accounting), to the detriment of information for decisionmaking (provided by management accounting).

In order to achieve the objective of the paper, we employed the correlation analysis to test the existence of relationships between several contingency factors and the assessed suitability of the information and reporting provided by the management accounting system, as well as the strength of such relationships.

The contribution of the present study to the body of related research is bidirectional. Firstly, the paper identifies some of the factors that influence the manner in which managers assess the usefulness of the information provided by management accounting; this may help both practitioners and academics to understand why management accounting is less developed in these countries than in other countries (particularly, the Western ones). Secondly, it explains the similarities and differences in the managers' perception on the management accounting usefulness within the two countries, in the light of several contingency factors; given the fact that management accounting should provide useful information for the decision-making process, such an investigation (from management perspective) brings to light some features of the management accounting systems within each of the two countries.

The remainder of the paper is organized as follows. The first section provides a brief review of the existing related literature and is followed, in the second section, by the description of the research design employed. The third section surveys the identified relationships between three considered variables (the company profile, the manager profile and the operations of the management accounting department), and the managers' perception on the information provided by management accounting. The final section points to the conclusions of the study, the limits of the research, as well as the future research directions.

\section{Literature review}

As a basis for our research, we reviewed prior studies, aiming firstly to assess the extent to which the contingency theory has been employed so far in the context of management accounting, and secondly to identify the independent variables most often related to accounting information.

\subsection{A contingency approach to management accounting}

Starting from a debate initiated by Zimmerman (2001), Malmi and Granlund (2009) wonder what is "the purpose and role of theory in management accounting research" and, provided an answer is found, whether current theories, originating in economics, sociology, psychology, or the organization theory, fulfil this purpose. Pointing to Luft and Shields (2002), who indicate that the management accounting theory focuses on explaining its causes and effects, they believe that the definitive reason for academics to understand the "causes, effects and functioning of management accounting" is to use this understanding in creating better management accounting practices.

The theoretical background of management accounting in its historical evolution is examined by Waveru (2010), who points to four distinct stages, each marked by a specific theory: the conventional wisdom up to 1960', the agency theory between 1960'-1970', the contingency theory between 1980'-1990' and the strategic management accounting from 1990' to date.

The contingency theory has been developed starting with the 60s (Burns and Stalker, 1967; Lawrence and Lorsch, 1967), evolving from sociological studies on organizational structure (Chenhall, 2003; Woods, 2009). One of the earliest approaches of contingency in relation with management accounting belongs to Hofstede (1967), who showed the significant impact of economic, technological and sociological factors on the functioning of budgetary systems. The influence of cultural factors was subsequently added (Hofstede, 1983; Brownell, 
1982; Brownell and Hirst, 1986). Hopwood (1972) and Otley (1978) pointed to the fact that every company operates in a specific environment, under the influence of different factors.

Contingency is placed by Hambrick and Lei (1985: 764) and Fisher (1995) between two extreme approaches, i.e. the situation-specific and the universalistic approach of the control systems. In the situation-specific rationale, the factors that affect each control system decision are unique, so there are no general rules and models that could be applied. The situation-specific model can practically be seen as a contingency approach with an extremely large number of contingent factors so that the identification of broad classes of factors is seen as futile. Research based on the situation-specific model usually takes the form of case studies. Contrariwise, the universalistic approach starts from the premise that "optimal control system design holds, to some degree, in all settings and firms" and can be analogously represented as a contingency with only one contingency setting.

Amid the two, the contingency theory starts from the premise that "universal solutions to problems in organizational control generally do not exist" (Otley, 2016). In this view, no single type of structure is appropriate for all organizations; rather the design and functioning of the organization are influenced by contingent factors. Eventually, the organizational effectiveness depends on the fit between the information system and contingent factors like the type of technology, the environmental volatility, or the size of the organization (Islam and Hu, 2012).

In the context of management accounting, the contingency theory shows that there is no accounting system that can be considered universally appropriate to all organizations, in all circumstances (Emmanuel et al., 1990), but rather the specific features of a system will depend on the specific circumstances of the organization, while the effectiveness of an accounting system depends on its capacity to adapt to changes in external and internal factors. Research on contingency relies on the existence of a link between the nature of the management accounting system and the enhanced performance.

However, research hasn't identified so far any key contingencies that would allow the development of prescriptions to suit different sets of circumstances; occasionally, different studies recommended conflicting solutions. Therefore, it is unlikely that research will manage to define a general contingency model, for an optimal control in all combinations of circumstances (Otley, 2016).

In the same line, Chenhall (2007) stresses that no single contingency theory exists, but rather "a variety of theories", continuing the reasoning of Otley (1980, p.413) who highlighted the need to associate the "specific aspects" of the accounting system that need to be explained with the "certain defined circumstances" and demonstrate the "appropriate matching" between the two. Islam and $\mathrm{Hu}$ (2012) highlight three types of questions addressed by the research on contingency in management accounting, regarding "the fit between organizational control and structure", "the impact of such fits on performance" and "the investigation of multiple contingencies and their impact on organizational design".

The next sub-section takes stock of independent variables frequently related by prior studies to accounting (including management accounting) information systems.

\subsection{The contingency variables}

In an early study, Gordon and Miller (1976) point to the environment, the organizational characteristics and the decision-making style as main classes of contingent variables for the design of accounting information systems. Currently, Otley (2016) points to the environmental uncertainty, expressed as perceived environmental uncertainty, as the one which attracted the widest attention on the part of the researchers.

In the four decades lying in between, numerous interrelations have been examined in the literature. We find external contingent factors related to the external environment (Khandwalla, 1977; Merchant, 1990; Chapmann, 1997; Hartmann, 2000), and the national culture (Hofstede, 1984; Harrison, 1992; O'Connor, 1995), with researchers most often emphasizing the environmental uncertainty and hostility. In equal measure, we find internal factors like the size of the organization (Khandwalla, 1972; Bruns and Waterhouse, 1975; Merchant 1981; Merchant, 1985), the technology (Khandwalla, 1977; Merchant, 1984; Dunk, 1992) and the strategy of the company (Miles and Snow, 1978, Gupta and Govindarajan, 1984; Simons, 1987; Chenhall and Morris, 1986). In the latter category, the appropriateness of the accounting data for the 
performance evaluation of business units (Fisher, 1995; Hartmann, 2000; Chenhall, 2003) can also be included.

Fisher (1995) classifies the contingent variables addressed in literature up to the moment of his contribution in five distinct categories: external environment; competitive strategy and mission; technology; unit, firm and industry variables; knowledge and observability factors. He stresses however that the variables listed under the five categories should not be considered exhaustive or independent and recommends that future research addresses "the causality and correlations among the contingent control variables".

A further classification was later performed by Merchant (1998), who defined three categories of variables: the first one included variables referring to people and organizations, the second one listed variables related to mission and strategy, and the last one included environmental and technological variables. Mockler (2002) identified three classes of variables, i.e. external variables, competition-related variables and companyspecific variables. In the same line, Nita (2009) divided contingency variables into internal, i.e. strategic and organisational variables, and external, i.e. sector and macroeconomic variables.

In a recent literature review on the topic of interest, Otley (2016) takes stock of and summarizes the independent variables most often used in contingency-based research, classifying them in major external and major internal variables. As such, the major external variables include the technology, the market competition or hostility, the environmental uncertainty and the national culture, while the major internal independent variables are the size and structure of the organization, its strategy and compensation and information systems, as well as psychological variables (like the tolerance for ambiguity), the employees' participation in the control systems, the position on the market, the product lifecycle stage, and systems change. Complementary, the dependent variables explained on a contingent basis, as identified in the literature by Otley (2016) are the performance and its measures, the budgeting behaviour, the management control system design and the use of it, the effectiveness, the job satisfaction, the change in practices, and the product innovation.

In the same context, Klassen (2014) points to a variable which is logically prior to strategy, i.e. the value logic, understood as the basic business model adopted by the organization. The effect of culture on the design of information systems is further widely investigated in literature, whereas many contributions rely on Hofstede's works (Hofstede, 1980; Hofstede et al., 2010). In an early stage, Hofstede (1980) identified four dimensions on which to characterize national cultures, i.e., individualism, masculinity and uncertainty avoidance that were subsequently completed by short-term vs. long-term emphasis, respectively by pragmatism and indulgence (Hofstede et al., 2010).

One of the major faults of the contingency-based research, as pointed to by Fisher (1995) is the "piecemeal way" of its performance, meaning that most often merely one contingent factor and one control attribute are examined at a time, despite the fact that the effectiveness of the control system design is determined by interactions between multiple contingent and control factors.

As specific illustrations, Gordon and Narayanan (1984) examined the relationship between the structure of the organization and the characteristics of information, finding that decision-makers perceive as important those characteristics of information that are related to the perceived environmental uncertainty.

The perceived usefulness of MAS information was examined by Chenhall and Morris (1986), who found that information perceived as useful by managers is broad in scope and timeliness. The link between the perceived usefulness of MAS information and the business performance was in effect extensively investigated in literature, in the following decade (Gul, 1991; Gul and Chia, 1994; Fisher, 1996). A significant gap in the adequacy of MAS information was ascertained in the manufacturing industry by Subramaniam (1993), whose analysis considered the perceived usefulness of MAS information by managers and the availability of this information.

The required characteristics of the MAS information were linked to the specific strategy of the firm, whereas Abernathy and Guthrie (1994) reported that companies with an orientation to continuous product-development and innovation employ effective broad-scope information systems, unlike companies with a narrow productmarket. Chong (1996) focused on the usefulness of broad-scope MAS information in connection with the uncertainty of the management tasks, finding that broadscope MAS information increases the effectiveness of managerial decisions and performance only under circumstances of high task uncertainty, otherwise implying a mere information overload.

More recently, Cadez and Guilding (2008) considered the company size, its strategy and market orientation as 
contingent variables, concluding that both the company's size and its strategic choices had a significant influence on the application of strategic management accounting. Aver and Cadez (2009) linked the participation of management accountants in the decision-making process rather to sociological developments.

With specific reference to the Eastern Europe, Haldma and Laats (2002) investigate the contingencies influencing the management accounting system, in the case of Estonia, as an example of transitional economy, pointing to the small number of studies on the development of management accounting in Eastern European countries. The research on accounting systems in this geographical area focuses on the financial accounting, proving that management accounting was here in the initial stage of development. More, the published research consists mainly of state-of-the-art type studies, without any theoretical framework, while research on management accounting practices in transition economies had been published, up to that moment, only with reference to India (Anderson and Lanen, 1999) and South Africa (Luther and Longden, 2001). On this particular case, Haldma and Laats (2002) find that the environmental contingency can be analysed distinctly, at the general business environment and the legal accounting environmental level. As for Estonia, the two authors argue that "within the Soviet accounting framework, management accounting existed in a very narrow sense" and it later developed on the background of an extant competition between the habits of the centrally planned economy on the one hand, and the need to solve daily management issues, on the other hand. The research confirms the influence of contingencies that had been pointed to by previous studies, like the tightening competition and the organization size, and introduces possible new factors, specific for transitional economies, like the legal accounting environment and the shortage of qualified accountants.

\section{Research design}

\subsection{Research methodology}

As indicated by Nita (2013), the contingency-based research on management accounting should include four components, i.e. the set of situational variables studied, the research questions relating to the methods of management accounting, the type of accounting theory employed (normative or positive) and the corresponding research methods. The present research focused on the positive theory of accounting, aiming to identify the strength of the relationship between specific variables and the assessment of managers in matters of usefulness of the management accounting information.

The empirical research was performed between May 2015 - March 2016, by means of a questionnaire-based online survey addressing randomly selected companies operating in Poland and Romania, in various industries, with different origin-based capital profiles.

The questionnaire was structured in four different sections: the first two provided a brief characterisation of the company, respectively of the respondent, the third section referred to the organisation of the management accounting system within the company, while the fourth section was meant to capture the managers' perception on the suitability of the information delivered by management accounting systems. The four sections consisted of a total of 26 half-open and closed questions, whereas the latter included single- and multiple-choice, span and matrix questions. They were selected and enunciated as a result of a thorough literature review, including studies on the purpose for which information is used (Baiman, 1982; Burns and McKinnon, 1992a; Burns and McKinnon, 1992b; Burns and McKinnon, 1993; Mendoza and Bescos, 2001), the information suitability (Burns and McKinnon, 1992a; Burns and McKinnon, 1992b; Burns and McKinnon, 1993; Mendoza and Bescos, 2001), as well as its qualitative features (Chenhall and Morris, 1986; Johnson and Kaplan, 1987; Pierce and O'Dea, 2003).

The survey resulted in 154 completed questionnaires, out of which 116 originated from Poland and 38 from Romania. One questionnaire corresponded to one respondent participating in the study, whereas there were also cases in which different questionnaires were completed by different managers from the same company.

The responses were analysed by means of the interdependence theory, meant to reveal correlations between variables. For this purpose, Czuprow's $T$ coefficient $-T_{C}$, Pearson's $C$ coefficient $-C_{p}$ and Cramer's $V$ coefficient $-V_{c}$ were applied to all variables under analysis, as standard coefficients used in descriptive statistics for searching correlations in collected data (Yule, 1912; Keller, 2012; Bergsma, 2013). All indicated coefficients have a value within the range of $[0,1]$. The closer the coefficients are to zero, the weaker the correlation between the variables, whereas the closer they are to 1 , the stronger the correlation between the analysed elements (Sobczyk, 2000). 
As previously mentioned, subject of the statistical analysis are the factors (variables) identified based on the reviewed literature (e.g. Blum, 2006; Budde, 2009). The factors were divided into 3 categories: (1) factors related to the company profile (type, size, origin of capital); (2) factors related to the manager profile (education, experience, and managed department); (3) factors related to the operations of the management accounting department (organisation, frequency of reporting and frequency of meetings between managers and management accountants).

As a brief overview of the first category of factors, the companies under analysis were divided into three size classes, based on their number of employees: small entities (with less than 10 employees), medium entities (with 10 to 200 employees) and large entities (with more than 200 employees). Considering their business area, these were classified into manufacturing and nonmanufacturing companies, whereas based on the origin of their capital, the sample included companies with foreign, domestic or shared capital.

The second category of factors defined the profile of the responding managers, considering their education (bachelor, master, post-graduate, doctoral studies), the management experience (short - under 6 years, average -6 to 10 years, long - over 10 years) and the managed department. Four different areas of operations were taken into account: (a) support departments, like HR, IT, finance; (b) sales and marketing; (c) purchases, logistics and production, and (d) other.

Considering the organisation of the management accounting department, within the third category, two distinct options were considered: (a) management accounting is performed by a distinct department of the company; (b) management accounting is performed within other departments or processes. The reporting frequency was classified into three classes: high (daily and upon managers' request), average (once a week) and low (once a month). The same three frequency classes were employed with regard to the frequency of meetings between management accountants and managers, a fourth option was however considered here, i.e. no meetings with management accountants.

\subsection{Sample profile}

The empirical research covered companies from different sectors, of a different size and with various sources of capital, operating in Poland and Romania (see Table no. 1).

\section{Table no. 1. Profile of the companies participating in the survey}

\begin{tabular}{|c|c|c|c|c|}
\hline \multirow{2}{*}{ Company profile } & \multicolumn{3}{|c|}{ ROM } & \multicolumn{2}{c|}{ POL } \\
\cline { 2 - 5 } & Number & $\%$ & Number & $\%$ \\
\hline Type of company & \multicolumn{3}{|c|}{} \\
\hline Manufacturer & 23 & $61 \%$ & 60 & $52 \%$ \\
\hline Service & 11 & $29 \%$ & 42 & $36 \%$ \\
\hline Trade & 4 & $11 \%$ & 14 & $12 \%$ \\
\hline Origin of capital & \multicolumn{4}{|c|}{} \\
\hline $100 \%$ domestic & 11 & $29 \%$ & 34 & $29 \%$ \\
\hline $100 \%$ foreign & 16 & $42 \%$ & 66 & $57 \%$ \\
\hline share of foreign & 11 & $29 \%$ & 16 & $14 \%$ \\
\hline Number of employees & \multicolumn{4}{|c|}{} \\
\hline$<10$ & 2 & $5 \%$ & 12 & $10 \%$ \\
\hline $11-50$ & 4 & $11 \%$ & 12 & $10 \%$ \\
\hline $51-250$ & 9 & $24 \%$ & 20 & $17 \%$ \\
\hline$>250$ & 23 & $61 \%$ & 72 & $62 \%$ \\
\hline Annual turnover in 000 000 EUR & \multicolumn{4}{|c|}{} \\
\hline$<2$ & 5 & $13 \%$ & 16 & $14 \%$ \\
\hline $2-10$ & 8 & $21 \%$ & 22 & $19 \%$ \\
\hline $11-50$ & 13 & $34 \%$ & 8 & $7 \%$ \\
\hline $51-200$ & 5 & $13 \%$ & 12 & $10 \%$ \\
\hline$>200$ & 7 & $18 \%$ & 58 & $50 \%$ \\
\hline
\end{tabular}

Source: Authors' own processing 
Both the Polish and the Romanian sample are dominated by manufacturing companies, large entities in terms of number of employees, mainly with foreign capital. The best represented sectors in the Romanian sample are the automotive, the food and beverages, the IT \& new technologies, the telecom and the clothing \& textiles industry, while in Poland most of the surveyed companies belong to the consumer goods, the building and construction, the IT \& new technologies, the consulting and the healthcare sector.

Table no. 2 summarizes the profile of the responding managers, in respect of their professional experience.

Table no. 2. The experience of the surveyed managers

\begin{tabular}{|l|c|c|c|c|}
\hline \multirow{2}{*}{ Experience } & \multicolumn{2}{|c|}{ ROM } & \multicolumn{2}{c|}{ POL } \\
\cline { 2 - 5 } & Number & $\%$ & Number & $\%$ \\
\hline$<1$ & 1 & $3 \%$ & 10 & $9 \%$ \\
\hline $1-5$ & 8 & $21 \%$ & 28 & $24 \%$ \\
\hline $6-10$ & 18 & $47 \%$ & 44 & $38 \%$ \\
\hline $11-15$ & 7 & $18 \%$ & 14 & $12 \%$ \\
\hline$>15$ & 4 & $11 \%$ & 20 & $17 \%$ \\
\hline TOTAL & 38 & $100 \%$ & 116 & $100 \%$ \\
\hline
\end{tabular}

Source: Authors' own processing

We observe that, in both countries, the best-represented experience classes are 6 to 10 years, followed by 1 to 5 years.

Table no. 3 illustrates the educational profile of the responding managers, where we observe that most respondents in both samples hold a Master's degree, yet the MBA and the PhD are more frequently encountered among Polish managers.

\begin{tabular}{|c|c|c|c|c|}
\hline \multirow{2}{*}{ Education background } & \multicolumn{2}{|c|}{ ROM } & \multicolumn{2}{|c|}{ POL } \\
\hline & Number & $\%$ & Number & $\%$ \\
\hline High school degree & 2 & $5 \%$ & 0 & $0 \%$ \\
\hline Bachelor degree & 10 & $26 \%$ & 2 & $2 \%$ \\
\hline Master's degree & 26 & $68 \%$ & 114 & $98 \%$ \\
\hline Post graduate studies & 0 & $0 \%$ & 6 & $5 \%$ \\
\hline MBA & 5 & $13 \%$ & 46 & $40 \%$ \\
\hline $\mathrm{PhD}$ & 2 & $5 \%$ & 10 & $9 \%$ \\
\hline
\end{tabular}

Source: Authors' own processing

The surveyed managers come both from operations departments like production, logistics, purchasing or sales $(53 \%$ of the Romanian and $50 \%$ of the Polish managers) and from support departments like HR, IT or finance $(41 \%$ of the Romanian and $39 \%$ of the Polish managers).

In most of the examined entities (80\% of the Polish, respectively $62 \%$ of the Romanian companies), management accounting is performed within an independent department. Yet, there are companies that prefer to integrate management accountants with employees from different departments.

\section{Resullits and discussions}

According to the research objective, Czuprow's T coefficient - $T_{C}$, Pearson's $C$ coefficient - $C_{p}$ and Cramer's $V$ coefficient - $V_{c}$ were employed in order to 
investigate the strength of the relationship between the company profile, the manager profile and the operations of the management accounting department, on the one hand, and:

1. The managers' assessment of the extent to which the information provided by the management accounting is used in performing management tasks;

2. The managers' assessment of the suitability of certain types of information provided by the management accounting system, in the context of the management process;

3. The managers' assessment of specific quality characteristics of internal reports, prepared by management accountants;

4. The managers' assessment of specific communication channels for the information delivered by the management accounting system.

According to the Merchant's (1998) classification, the contingency variables considered by our study refer to people and organizations. They are mainly organizational variables, similar to Cadez and Guilding (2008) Gordon and Narayanan (1984), treated as internal factors in the context of management accounting. Among these, the size of the company and the origin of the capital are seen as most important in literature (Nita, 2009).

\subsection{Factors determining the assessment of the extent to which the information provided by the management accounting system is employed as a support of the management process}

In order to determine the factors related to the assessment of the extent to which the information provided by the management accounting system is employed in performing management tasks, we examined the interdependence between this assessment and the following variables:

- the company profile (type of company, size, origin of capital);

- the manager profile (professional experience, education, managed department);

- the operations of the management accounting department (organisation, frequency of reporting, frequency of meetings between managers and management accountants).

The initial testing of the data showed that the company profile is a variable with no significant influence on managers' assessments (see Table no. 4).

\section{Table no. 4. The relationship between the company profile and the assessed suitability of the information provided by the MAS}

\begin{tabular}{|c|c|c|c|c|c|c|c|c|c|c|c|c|c|c|c|c|c|c|}
\hline \multirow{3}{*}{$\begin{array}{c}\text { Company profile } \\
\text { Country } \\
\text { Coefficient }\end{array}$} & \multicolumn{6}{|c|}{ Type of the company } & \multicolumn{6}{|c|}{ Size of the company } & \multicolumn{6}{|c|}{ Origin of the capital } \\
\hline & \multicolumn{3}{|c|}{ POL } & \multicolumn{3}{|c|}{ ROM } & \multicolumn{3}{|c|}{ POL } & \multicolumn{3}{|c|}{ ROM } & \multicolumn{3}{|c|}{ POL } & \multicolumn{3}{|c|}{ ROM } \\
\hline & $T_{c}$ & $\mathbf{V}_{\mathrm{c}}$ & $C_{p}$ & $T_{c}$ & $\mathbf{V}_{\mathrm{c}}$ & $C_{P}$ & $T_{c}$ & $\mathbf{V}_{\mathrm{c}}$ & $C_{P}$ & $\mathrm{~T}_{\mathrm{c}}$ & $\mathbf{V}_{\mathrm{c}}$ & $C_{P}$ & $T_{c}$ & $\mathbf{V}_{\mathrm{c}}$ & $C_{P}$ & $\mathrm{~T}_{\mathrm{c}}$ & $\mathbf{V}_{\mathrm{c}}$ & $C_{P}$ \\
\hline Long term planning & 0.19 & 0.24 & 0.23 & 0.15 & 0.18 & 0.18 & 0.22 & 0.26 & 0.35 & 0.15 & 0.25 & 0.18 & 0.13 & 0.16 & 0.22 & 0.17 & 0.20 & 0.28 \\
\hline Implementing the strategy & 0.11 & 0.13 & 0.13 & 0.13 & 0.16 & 0.16 & 0.21 & 0.25 & 0.34 & 0.17 & 0.21 & 0.28 & 0.16 & 0.19 & 0.26 & 0.13 & 0.13 & 0.18 \\
\hline Preparing budgets & 0.24 & 0.29 & 0.28 & 0.24 & 0.29 & 0.28 & 0.32 & 0.38 & 0.47 & 0.14 & 0.16 & 0.22 & 0.27 & 0.32 & 0.41 & 0.25 & 0.30 & 0.39 \\
\hline Performance measurement & 0.15 & 0.18 & 0.18 & 0.12 & 0.15 & 0.15 & 0.15 & 0.18 & 0.25 & 0.14 & 0.16 & 0.22 & 0.08 & 0.10 & 0.14 & 0.18 & 0.21 & 0.28 \\
\hline Increasing profitability & 0.17 & 0.21 & 0.20 & 0.24 & 0.28 & 0.27 & 0.17 & 0.21 & 0.28 & 0.19 & 0.22 & 0.30 & 0.14 & 0.16 & 0.23 & 0.15 & 0.18 & 0.25 \\
\hline Managing own department & 0.16 & 0.19 & 0.18 & 0.32 & 0.38 & 0.36 & 0.05 & 0.07 & 0.09 & 0.22 & 0.26 & 0.35 & 0.22 & 0.26 & 0.34 & 0.24 & 0.29 & 0.38 \\
\hline $\begin{array}{l}\text { Make or buy/ outsourcing } \\
\text { decision-making }\end{array}$ & 0.20 & 0.23 & 0.23 & 0.22 & 0.26 & 0.25 & 0.21 & 0.25 & 0.34 & 0.08 & 0.10 & 0.13 & 0.15 & 0.18 & 0.24 & 0.19 & 0.23 & 0.30 \\
\hline $\begin{array}{l}\text { Making investment } \\
\text { decisions }\end{array}$ & 0.19 & 0.23 & 0.23 & 0.20 & 0.24 & 0.24 & 0.09 & 0.11 & 0.16 & 0.16 & 0.19 & 0.26 & 0.13 & 0.15 & 0.21 & 0.16 & 0.19 & 0.26 \\
\hline $\begin{array}{l}\text { Making decisions } \\
\text { regarding } R \& D\end{array}$ & 0.10 & 0.12 & 0.12 & 0.47 & 0.56 & 0.49 & 0.11 & 0.13 & 0.18 & 0.27 & 0.32 & 0.41 & 0.17 & 0.20 & 0.27 & 0.40 & 0.47 & 0.56 \\
\hline Cost reduction & 0.08 & 0.09 & 0.09 & 0.27 & 0.32 & 0.31 & 0.14 & 0.17 & 0.23 & 0.18 & 0.22 & 0.29 & 0.11 & 0.13 & 0.18 & 0.14 & 0.23 & 0.17 \\
\hline Cost control & 0.03 & 0.04 & 0.04 & 0.25 & 0.30 & 0.29 & 0.20 & 0.24 & 0.32 & 0.11 & 0.13 & 0.18 & 0.14 & 0.17 & 0.23 & 0.18 & 0.22 & 0.29 \\
\hline Assessing internal projects & 0.07 & 0.08 & 0.08 & 0.27 & 0.32 & 0.31 & 0.14 & 0.17 & 0.23 & 0.14 & 0.17 & 0.23 & 0.21 & 0.25 & 0.33 & 0.11 & 0.14 & 0.19 \\
\hline
\end{tabular}

Source: Authors' own processing 
Table no. 4 shows a weak or very weak relationship between the company profile and the suitability assessment of management accounting information. These results are quite puzzling as, according to previous contributions to literature, the company size and type should have a significant impact on the development of management accounting (Otley, 2016; Cadez and Guilding, 2008).

Only a moderate relationship is noticed between the size of the company and the origin of its capital, on the one hand, and the suitability assessment of the information for the budget preparation, on the other hand, in case of Polish managers. A moderate relationship can also be observed between the type of company, the origin of the capital and the size of the enterprise (to a lesser extent) on the one hand, and the suitability assessment of the information for R\&D decision making, on the other hand, in case of Romanian managers.

Based on the preliminary variable analysis, neither the manager profile has a strong influence on managers' assessments (see Table no. 5).

\section{Table no. 5 . The relationship between the manager profile and the assessed suitability of the information provided by the MAS}

\begin{tabular}{|c|c|c|c|c|c|c|c|c|c|c|c|c|c|c|c|c|c|c|}
\hline Manager profile & \multicolumn{6}{|c|}{ Professional exeprience } & \multicolumn{6}{|c|}{ Education } & \multicolumn{6}{|c|}{ Managed department } \\
\hline Country & \multicolumn{3}{|c|}{ POL } & \multicolumn{3}{|c|}{ ROM } & \multicolumn{3}{|c|}{ POL } & \multicolumn{3}{|c|}{ ROM } & \multicolumn{3}{|c|}{ POL } & \multicolumn{3}{|c|}{ ROM } \\
\hline Coefficient & Tc & $V_{c}$ & $C_{p}$ & Tc & $\mathbf{V}_{\mathrm{c}}$ & $C_{P}$ & Tc & $\mathrm{V}_{\mathrm{c}}$ & $C_{p}$ & Tc & $V_{c}$ & $C_{\mathrm{P}}$ & Tc & $V_{c}$ & $C_{P}$ & Tc & $V_{c}$ & $C_{p}$ \\
\hline
\end{tabular}

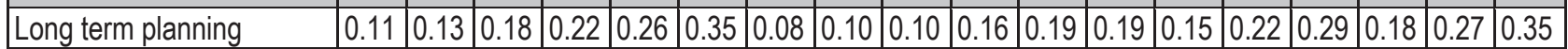

\begin{tabular}{|l|l|l|l|l|l|l|l|l|l|l|l|l|l|l|l|l|l|l|}
\hline Implementing the strategy & 023 & 0.27 & 0.36 & 0.13 & 0.16 & 0.22 & 0.02 & 0.02 & 0.02 & 0.12 & 0.15 & 0.14 & 0.20 & 0.29 & 0.38 & 0.14 & 0.21 & 0.29 \\
\hline
\end{tabular}

\begin{tabular}{|l|l|l|l|l|l|l|l|l|l|l|l|l|l|l|l|l|l|l|}
\hline Preparing budgets & 0.19 & 0.23 & 0.31 & 0.14 & 0.17 & 0.24 & 0.08 & 0.10 & 0.10 & 0.13 & 0.16 & 0.16 & 0.37 & 0.54 & 0.61 & 0.25 & 0.36 & 0.46 \\
\hline
\end{tabular}

\begin{tabular}{|l|c|c|c|c|c|c|c|c|c|c|c|c|c|c|c|c|c|c|}
\hline Performance & 0.19 & 0.23 & 0.31 & 0.14 & 0.17 & 0.24 & 0.32 & 0.38 & 0.35 & 0.13 & 0.16 & 0.16 & 0.18 & 0.26 & 0.35 & 0.17 & 0.25 & 0.34 \\
\hline
\end{tabular}

measurement

\begin{tabular}{|llllllllllllll|l|l|l|l|l|l|l|l|l|}
\hline Increasing profitability & 0.14 & 0.17 & 0.23 & 0.24 & 0.28 & 0.37 & 0.11 & 0.13 & 0.12 & 0.17 & 0.20 & 0.20 & 0.14 & 0.21 & 0.29 & 0.19 & 0.28 & 0.37 \\
\hline
\end{tabular}

\begin{tabular}{|l|l|l|l|l|l|l|l|l|l|l|l|l|l|l|l|l|l|l|}
\hline Managing own department & 0.13 & 0.15 & 0.21 & 0.15 & 0.18 & 0.25 & 0.24 & 0.29 & 0.28 & 0.19 & 0.23 & 0.22 & 0.13 & 0.20 & 0.27 & 0.27 & 0.39 & 0.48 \\
\hline
\end{tabular}

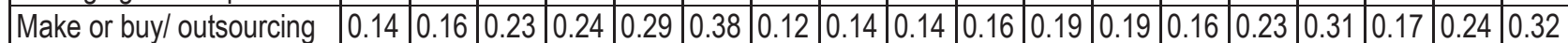

decision-making

\begin{tabular}{|l|l|l|l|l|l|l|l|l|l|l|l|l|l|l|l|l|l|l|l|}
\hline $\begin{array}{l}\text { Making investment } \\
\text { dacis }\end{array}$ & 0.11 & 0.14 & 0.19 & 0.16 & 0.19 & 0.26 & 0.11 & 0.13 & 0.13 & 0.10 & 0.11 & 0.12 & 0.21 & 0.31 & 0.40 & 0.15 & 0.22 & 0.29 \\
\hline
\end{tabular}

decisions

\begin{tabular}{|l|l|l|l|l|l|l|l|l|l|l|l|l|l|l|l|l|l|l|}
\hline Making decisions & 0.20 & 0.24 & 0.32 & 0.17 & 0.20 & 0.28 & 0.22 & 0.26 & 0.25 & 0.06 & 0.07 & 0.07 & 0.14 & 0.20 & 0.28 & 0.28 & 0.45 & 0.54 \\
\hline
\end{tabular}

regarding R\&D

\begin{tabular}{|llllllllllllll|l|l|l|l|l|l|l|l|l|}
\hline Cost reduction & 0.07 & 0.09 & 0.12 & 0.15 & 0.18 & 0.25 & 0.06 & 0.07 & 0.07 & 0.12 & 0.14 & 0.14 & 0.19 & 0.27 & 0.36 & 0.19 & 0.28 & 0.37 \\
\hline Cost
\end{tabular}

\begin{tabular}{|l|c|c|c|c|c|c|c|c|c|c|c|c|c|c|c|c|c|c|}
\hline Cost control & 0.12 & 0.15 & 0.20 & 0.22 & 0.26 & 0.34 & 0.07 & 0.09 & 0.09 & 0.11 & 0.13 & 0.13 & 0.11 & 0.16 & 0.22 & 0.23 & 0.33 & 0.43 \\
\hline
\end{tabular}

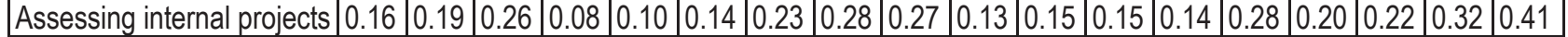

Source: Authors' own processing

The results show a weak or very weak relationship between the education and the professional experience of the managers on the one hand, and the suitability assessment of management accounting information, on the other hand.

Moderate relationships can be identified between the managed department and the assessed suitability of the information. In the case of Polish managers, the moderate interdependence refers to the assessed suitability of the information for budget preparation and investment decision, while in the case of Romanian managers, it refers to budget preparation, internal projects, cost reduction and control and R\&D decisions. What should be noted is that, in Polish companies, the relationship between the managed department and the use of the information provided by the accounting system for the purpose of preparing budgets and supporting management decisions is slightly stronger $\left(C_{p}=0.61\right)$. The results confirm that the type of the managed department exerts influence on the use of the information by the manager.

The third variable considered regards the organisation and operations of the management accounting department (see Table no. 6). 


\section{Table no. 6. The relationship between the operations of the MA department and the assessed suitability of the} information provided by the MAS

\begin{tabular}{|c|c|c|c|c|c|c|c|c|c|c|c|c|c|c|c|c|c|c|}
\hline \multirow{3}{*}{$\begin{array}{c}\begin{array}{c}\text { Operations of the MA } \\
\text { department }\end{array} \\
\text { Country } \\
\text { Coefficient } \\
\end{array}$} & \multicolumn{6}{|c|}{ Organisation of MA } & \multicolumn{6}{|c|}{ Frequency of reporting } & \multicolumn{6}{|c|}{ Frequency of meetings } \\
\hline & \multicolumn{3}{|c|}{ POL } & \multicolumn{3}{|c|}{ ROM } & \multicolumn{3}{|c|}{ POL } & \multicolumn{3}{|c|}{ ROM } & \multicolumn{3}{|c|}{ POL } & \multicolumn{3}{|c|}{ ROM } \\
\hline & $T_{c}$ & $V_{c}$ & $C_{p}$ & $T_{c}$ & $\mathrm{~V}_{\mathrm{c}}$ & $C_{p}$ & $T_{c}$ & $\mathrm{~V}_{\mathrm{c}}$ & $C_{P}$ & $T_{c}$ & $\mathbf{V}_{\mathrm{c}}$ & $C_{P}$ & $T_{c}$ & $\mathrm{~V}_{\mathrm{c}}$ & $C_{p}$ & $T_{c}$ & $\mathbf{V}_{\mathrm{c}}$ & $C_{p}$ \\
\hline Long term planning & 0.12 & & 0.14 & 0.17 & 0.20 & & 0.20 & 0.23 & 0.31 & 0.32 & 0.38 & 0.47 & 0.11 & 0.13 & 0.19 & 0.22 & & \\
\hline & & & & 0.15 & & & 0. & & 29 & 21 & & 33 & 28 & & & 28 & & \\
\hline er & & & & 0. & & & 0. & & & 22 & & 0 & 27 & & & 19 & & \\
\hline Perfor & 0.16 & & 0.19 & 0.29 & & 0. & 0 & & 0 & 0. & & 0 & 32 & & & 27 & & 0 \\
\hline ncre & 0.13 & & 0.15 & 0.31 & & 0. & & & 28 & 20 & & 32 & 22 & & & 21 & & 0. \\
\hline$\overline{\operatorname{Man}}$ & 0. & 0.15 & 0.15 & 0.07 & 0. & 0.09 & 0.23 & 27 & 0.36 & 0.12 & 14 & 0.20 & 0.12 & & 0.20 & 0.17 & 20 & 0.2 \\
\hline & 0.26 & 0.31 & 0.30 & 0.17 & 0.20 & 0.20 & 0.18 & 0.21 & 0.29 & 0.24 & 0.29 & 0.38 & 0.34 & 0.40 & 0.49 & 0.19 & 0.23 & \\
\hline & 0.13 & 0.16 & 0.16 & 0.14 & 0.16 & 0.16 & 0.26 & 0.31 & 0.40 & 0.20 & 0.24 & 0.32 & 0.20 & 0.24 & 0.32 & 0.25 & & \\
\hline Making decisions & 0.09 & 0.11 & 0.11 & 0.06 & 0.07 & 0.07 & 0.12 & 0.15 & 0.20 & 0.19 & 0.23 & 0.31 & 0.15 & 0.17 & 0.24 & 0.19 & 0.23 & \\
\hline ost re & 0.13 & 0.15 & 0.15 & 0.25 & 0.30 & 0.29 & 0.11 & 0.13 & 0.18 & 0.09 & 0.11 & 0.16 & 0.12 & 0.14 & 0.20 & 0.16 & 0.19 & 0.2 \\
\hline Cost covitiot & 0.14 & 0.16 & 0.16 & 0.17 & 0.26 & 0.26 & 0.16 & 0.19 & 0.26 & 0.31 & 0.37 & 0.46 & 0.11 & 0.13 & 0.19 & 0.22 & 0.26 & $0.3^{3}$ \\
\hline ssessing internal & 0.14 & 0.17 & 0.17 & 0.08 & 0.11 & 0.11 & 0.17 & 0.21 & 0.28 & 0.06 & 0.07 & 0.10 & 0.17 & 0.20 & 0.28 & 0.23 & $\begin{array}{l}30.28 \\
\end{array}$ & \begin{tabular}{|l|l|} 
\\
\end{tabular} \\
\hline
\end{tabular}

Source: Authors' own processing

The results show a generally weak or very weak relationship between the organisation of the accounting department on the one hand, and the suitability assessment of management accounting information, on the other hand. However, we notice a moderate interdependence between the reporting frequency and the use of information to support investment decisions in companies in Poland, respectively between reporting frequency and longterm planning and cost control, in business organisations from Romania.

What is interesting to note is that the frequency of meetings with the employees of the management accounting department determines to a moderate extent the use of information derived from this department for a relatively large amount of activities supporting the work of managers. It includes, among others, the implementation of strategies and performance measurement in the examined companies from Poland and Romania, and also in the case of Polish managers, preparing budgets and making short-term decisions.

The results show that, although the organisational issues around the management accountant (department, position, function) or the internal reporting frequency are not essential in determining the suitability of the specific information. Staff meetings with the employees of the accounting department are deemed relevant by the surveyed managers, while their frequency determines the use of the information as a management support to a higher extent than the other examined factors.

\subsection{Factors determining the assessed suitability of selected information provided by the management accounting system}

The assessed suitability of selected information provided by the management accounting system, as a support of the management process, was correlated with the same three variables: the company profile, the manager profile, the operations of the management accounting department.

The preliminary testing of the data showed that the company profile is not a variable with a strong influence on the assessment of selected types of information (Table no. 7). 
Table no. 7. The relationship between the company proffle and the assessed suitability of selected information provided by the MAS

\begin{tabular}{|c|c|c|c|c|c|c|c|c|c|c|c|c|c|c|c|c|c|c|}
\hline Company profile & \multicolumn{6}{|c|}{ Type of the company } & \multicolumn{6}{|c|}{ Size of the company } & \multicolumn{6}{|c|}{ Origin of the capital } \\
\hline Country & \multicolumn{3}{|c|}{ POL } & \multicolumn{3}{|c|}{ ROM } & \multicolumn{3}{|c|}{ POL } & \multicolumn{3}{|c|}{ ROM } & \multicolumn{3}{|c|}{ POL } & \multicolumn{3}{|c|}{ ROM } \\
\hline Coefficient & $T_{c}$ & $V_{c}$ & $C_{p}$ & $\mathrm{~T}_{\mathrm{c}}$ & $V_{c}$ & $C_{p}$ & Tc & $\mathbf{V}_{\mathrm{c}}$ & $C_{p}$ & Tc & $V_{c}$ & $C_{p}$ & Tc & $V_{c}$ & $C_{p}$ & Tc & $\mathrm{V}_{\mathrm{c}}$ & $C_{p}$ \\
\hline sts & 0.21 & 0.25 & 0.24 & 0.21 & 0.21 & 0.21 & 0.16 & 0.20 & 0.27 & 0.08 & 0.13 & 0.13 & 0.23 & 0.27 & 0.36 & 0.20 & 0.24 & 0.32 \\
\hline evenues & .11 & 0.13 & 0.13 & 0.11 & 0.14 & 0.14 & 0.15 & 0.18 & 0.25 & 0.05 & 0.18 & 0.25 & 0.20 & 0.24 & 0.32 & 0.20 & 0.24 & $0.2^{2}-x$ \\
\hline inanci & 0.10 & 0.12 & 0.12 & 0.10 & 0.19 & 0.20 & 0.18 & 0.22 & 0.29 & 0.21 & 0.25 & 0.33 & 0.21 & 0.24 & 0.33 & 0.33 & 0.39 & 0.49 \\
\hline inancial indicators & 0.10 & 0.12 & 0.12 & 0.10 & 0.15 & 0.14 & 0.20 & 0.24 & 0.32 & 0.16 & 0.21 & 0.28 & 0.26 & 0.30 & 0.40 & 0.45 & 0.53 & 0.60 \\
\hline Jariance analysis & 0.06 & 0.07 & 0.07 & 0.06 & 0.18 & 0.18 & 0.20 & 0.24 & 0.32 & 0.23 & 0.28 & 0.37 & 0.20 & 0.23 & 0.31 & 0.29 & 0.35 & 0.44 \\
\hline ctual financial da & 0.20 & 0.24 & 0.23 & 0.20 & 0.22 & 0.22 & 0.30 & 0.35 & 0.45 & 0.27 & 0.32 & 0.41 & 0.16 & 0.19 & 0.26 & 0.21 & 0.25 & 0.33 \\
\hline lanned financial data & 0.10 & 0.12 & 0.12 & 0.10 & 0.10 & 0.10 & 0.12 & 0.15 & 0.20 & 0.23 & 0.27 & 0.36 & 0.20 & 0.24 & 0.33 & 0.14 & 0.17 & 0.23 \\
\hline on-financial indicators & 0.14 & 0.16 & 0.16 & 0.14 & 0.12 & 0.12 & 0.29 & 0.34 & 0.43 & 0.15 & 0.18 & 0.25 & 0.12 & 0.14 & 0.19 & 0.31 & 0.37 & 0.46 \\
\hline
\end{tabular}

Source: Authors' own processing

Table no. 7 shows a weak or very weak relationship between the type of the company and the use of information for management purposes. Further, we observe a moderate relationship between the size of the company and the use of actual financial data in both countries, as well as between the size of the company and the use of non-financial ratios in Poland. The origin of the capital and the use of financial indicators exhibit as well a moderate interdependence in both countries, with a slightly higher coefficient in the case of Romania $\left(C_{P}=0.6\right)$. Romanian companies also display a moderate relationship between the origin of the capital and the use of information on financial results, variance analysis and non-financial ratios. The figures actually indicate that although managers are basically provided with information on costs, revenues and financial results, managers of mainly larger companies, or companies with foreign capital located in Romania also employ other types of information, delivered by management accounting, as a support of the management process. A plausible explanation of this state of the art may be that transnational corporate headquarters imposing standard solutions on their branch offices have a significant influence on the type of information used as a management support.

The second variable considered in the analysis, i.e. the manager profile, was proven not to have a strong influence on the considered assessments (see Table no. 8).

\section{Table no. 8. The relationship between the manager proffle and the assessed suitability of selected information provided by the MAS}

\begin{tabular}{|c|c|c|c|c|c|c|c|c|c|c|c|c|c|c|c|c|c|c|}
\hline \multirow{3}{*}{$\begin{array}{c}\text { Manager profile } \\
\text { Country } \\
\text { Coefficient }\end{array}$} & \multicolumn{6}{|c|}{ Professional experience } & \multicolumn{6}{|c|}{ Education } & \multicolumn{6}{|c|}{ Managed department } \\
\hline & \multicolumn{3}{|c|}{ POL } & \multicolumn{3}{|c|}{ ROM } & \multicolumn{3}{|c|}{ POL } & \multicolumn{3}{|c|}{ ROM } & \multicolumn{3}{|c|}{ POL } & \multicolumn{3}{|c|}{ ROM } \\
\hline & $T_{c}$ & $V_{c}$ & $C_{p}$ & $T_{c}$ & $V_{c}$ & $C_{p}$ & $T_{c}$ & $\mathbf{v}_{\mathrm{c}}$ & $C_{p}$ & $T_{c}$ & $\mathrm{~V}_{\mathrm{c}}$ & $C_{p}$ & $T_{c}$ & $\mathrm{~V}_{\mathrm{c}}$ & $C_{p}$ & $T_{c}$ & $V_{c}$ & $C_{p}$ \\
\hline Costs & 0.14 & 0.16 & 0.22 & 0.11 & 0.18 & 0.19 & 0.01 & 0.01 & 0.01 & 0.07 & 0.09 & 0.09 & 0.14 & 0.20 & 0.27 & 0.22 & 0.33 & $\begin{array}{ll}0.42 \\
0.45\end{array}$ \\
\hline Revenues & 0.26 & 0.31 & 0.40 & 0.25 & 0.29 & 0.38 & 0.25 & 0.30 & 0.29 & 0.13 & 0.16 & 0.17 & 0.15 & 0.22 & 0.30 & 0.19 & 0.23 & \begin{tabular}{l|l|}
0.37 \\
\end{tabular} \\
\hline Financial results & 0.15 & 0.17 & 0.24 & 0.23 & 0.27 & 0.36 & 0.07 & 0.08 & 0.08 & 0.08 & 0.10 & 0.10 & 0.11 & 0.15 & 0.21 & 0.22 & 0.26 & 0.41 \\
\hline Financial indicators & 0.17 & 0.20 & 0.27 & 0.27 & 0.32 & 0.42 & 0.05 & 0.06 & 0.06 & 0.10 & 0.12 & 0.13 & 0.12 & 0.17 & 0.24 & 0.23 & 0.27 & 0.43 \\
\hline Variance a & 0.25 & 0.29 & 0.38 & 0.29 & 0.34 & 0.44 & 0.11 & 0.13 & 0.13 & 0.13 & 0.15 & 0.15 & 0.17 & 0.25 & 0.33 & 0.20 & 0.24 & 0.39 \\
\hline Actual finar & 0.18 & 0.21 & 0.28 & 0.13 & 0.16 & 0.22 & 0.06 & 0.08 & 0.08 & 0.29 & 0.35 & 0.33 & 0.16 & 0.23 & 0.31 & 0.43 & 0.51 & 0.67 \\
\hline Planned financ & 0.13 & 0.16 & 0.22 & 0.23 & 0.28 & 0.36 & 0.18 & 0.22 & 0.21 & 0.21 & 0.25 & 0.24 & 0.15 & 0.21 & 0.29 & 0.28 & 0.33 & 0.50 \\
\hline \begin{tabular}{|l} 
Non-financial indicators \\
\end{tabular} & 0.16 & 0.19 & 0.26 & 0.22 & 0.26 & 0.35 & 0.09 & 0.11 & 0.11 & 0.09 & 0.10 & 0.10 & 0.18 & 0.26 & 0.35 & 0.18 & 0.21 & 0.34 \\
\hline
\end{tabular}

Source: Authors' own processing 
The results point to a weak or very weak relationship between the education of the surveyed managers and the use of selected types of information. In turn, we observe a moderate relationship between the work experience of the managers and the employment of information on revenues in Poland, while in Romania moderate dependencies are proven between work experience and the use of information on financial indicators and variations, as well as between the type of the managed department and the use of information on costs, financial results, financial indicators and planned financial data. Romania also exhibits a stronger relationship between the type of the managed department and the application of actual financial data $(C p=0.67)$, while in Poland, the relationship between the type of department and the type of information used in each of the examined cases is weak or very weak.

The last variable examined in this area regards the operations of the management accounting department (see Table no. 9), which proved to be a rather weak determinant of the specific assessments.

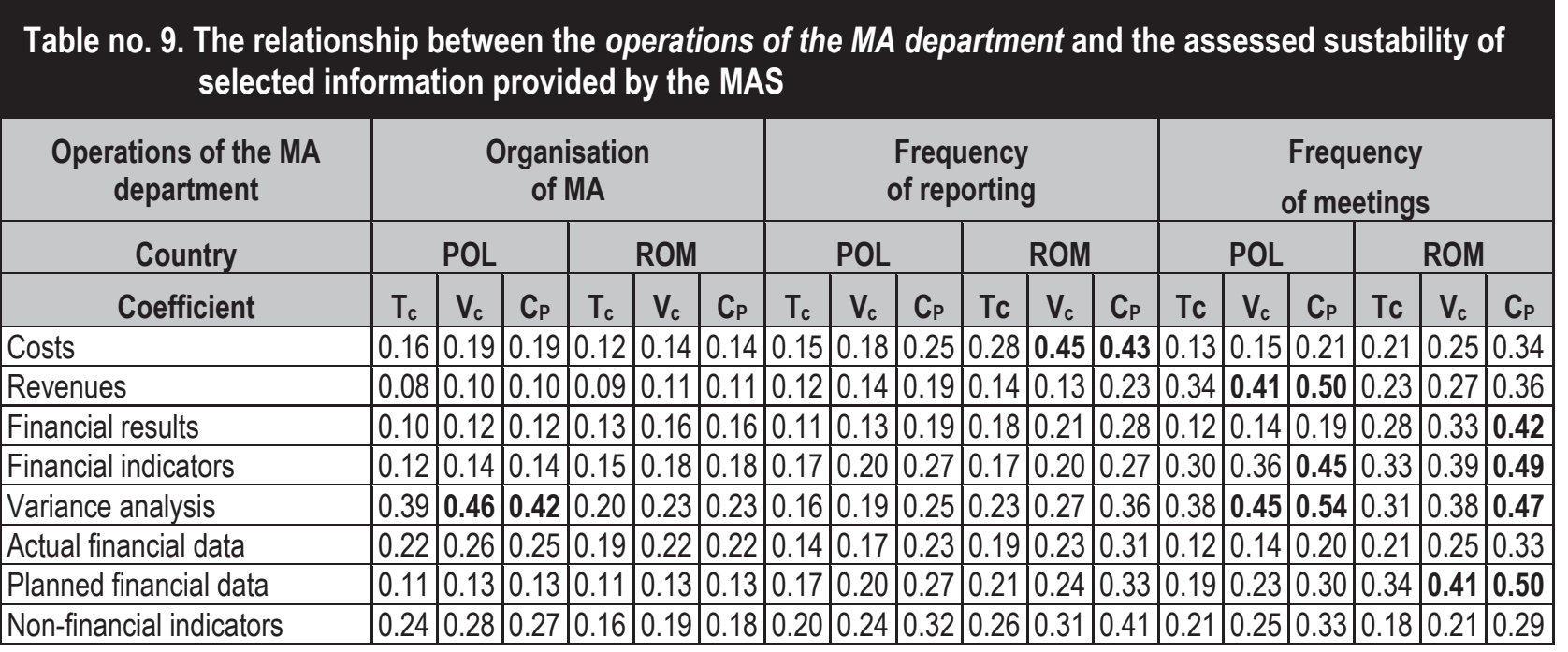

Source: Authors' own processing

The collected results of the statistical analysis substantiate a weak or very weak relationship between the organisation of management accounting in the examined companies and the information employed as a management support. The only moderate dependence is observed in Polish companies with regard to the variance analysis. Neither the frequency of reporting is strongly connected with the suitability of selected information as a management support in Polish organisations. Yet, the case of Romania exhibits a moderate relationship between the frequency of reporting and the suitability of information on costs and non-financial ratios. The frequency of the meetings with management accountants is, however, a factor with a significant impact on the assessments of the surveyed managers. Relationships between the frequency of meetings and the suitability of information on variations and financial indicators are observed both in Poland and in Romania. More, the frequency of meetings is further linked in Romania to the information on financial results and planned financial data, and in Poland to information on the revenues. Hence, it can be stated that the meetings between managers and management accountants play a leading part in the context of the assessed suitability of information on costs, revenues, current or planned financial data.

\subsection{Factors determining the assessment of the quality characteristics of management accounting reports}

The same three variables considered so far (the company profile, the managers' profile and the operations of the management accounting department) were employed in analysing the assessment of the quality characteristics of management accounting reports. In this context, the company profile showed a weak or very weak influence on the specific assessments (see Table no. 10). 


\section{Table no. 10. The relationship between the company profile and the assessment of the quality characteristics} of MA reports

\begin{tabular}{|c|c|c|c|c|c|c|c|c|c|c|c|c|c|c|c|c|c|c|}
\hline Company profile & \multicolumn{6}{|c|}{ Type of the company } & \multicolumn{6}{|c|}{ Size of the company } & \multicolumn{6}{|c|}{ Origin of the capital } \\
\hline Country & \multicolumn{3}{|c|}{ POL } & \multicolumn{3}{|c|}{ ROM } & \multicolumn{3}{|c|}{ POL } & \multicolumn{3}{|c|}{ ROM } & \multicolumn{3}{|c|}{ POL } & \multicolumn{3}{|c|}{ ROM } \\
\hline Coefficient & $T_{c}$ & $\mathbf{V}_{\mathbf{c}}$ & $C_{P}$ & $T_{c}$ & $\mathbf{V}_{\mathbf{c}}$ & $C_{p}$ & $T_{c}$ & $V_{c}$ & $C_{p}$ & $T_{c}$ & $V_{c}$ & $C_{P}$ & $T_{c}$ & $\mathbf{V}_{\mathbf{c}}$ & $C_{P}$ & $T_{c}$ & $\mathbf{V}_{\mathbf{c}}$ & $C_{P}$ \\
\hline mprehe & 0.22 & 0.26 & 0.25 & 0.12 & 0.15 & 0.14 & 0.24 & 0.28 & 0.37 & 0.09 & 0.11 & 0.15 & 0.08 & 0.10 & 0.14 & 0.19 & 0.23 & 0.31 \\
\hline omplete & 0.17 & 0.20 & 0.19 & 0.12 & 0.15 & 0.15 & 0.21 & 0.25 & 0.33 & 0.17 & 0.20 & 0.27 & 0.16 & 0.19 & 0.26 & 0.15 & 0.18 & \\
\hline arity & 0.18 & 0.21 & 0.21 & 0.26 & 0.31 & 0.29 & 0.24 & 0.28 & 0.37 & 0.16 & 0.19 & 0.26 & 0.12 & 0.15 & 0.20 & 0.24 & 0.29 & \\
\hline ne a & 0.25 & 0.30 & 0.28 & 0.14 & 0.17 & 0.17 & 0.19 & 0.23 & 0.31 & 0.13 & 0.16 & 0.22 & 0.15 & 0.18 & 0.24 & 0.13 & 0.15 & \\
\hline evel & 0.17 & 0.20 & 0.20 & 0.12 & 0.15 & 0.15 & 0.18 & 0.22 & 0.30 & 0.17 & 0.20 & 0.27 & 0.13 & 0.15 & 0.21 & 0.28 & 0.34 & .043 \\
\hline $\begin{array}{l}\text { mpa } \\
\text { anda }\end{array}$ & 0.10 & 0.12 & 0.12 & 0.26 & 0.31 & 0.29 & 0.15 & 0.18 & 0.24 & 0.17 & 0.20 & 0.28 & 0.13 & 0.15 & 0.21 & 0.21 & 0.25 & 0.33 \\
\hline aphical re & 0.28 & 0.34 & 0.32 & 0.20 & 0.24 & 0.24 & 0.14 & 0.17 & 0.23 & 0.17 & 0.21 & 0.28 & 0.14 & 0.16 & 0.22 & 0.14 & 0.17 & 0.2 \\
\hline levanc & 0.31 & 0.36 & 0.34 & 0.13 & 0.15 & 0.15 & 0.22 & 0.26 & 0.35 & 0.14 & 0.16 & 0.22 & 0.31 & 0.37 & 0.46 & 0.21 & 0.25 & 0.3 \\
\hline mments & 0.21 & 0.25 & 0.24 & 0.14 & 0.17 & 0.16 & 0.14 & 0.17 & 0.24 & 0.32 & 0.39 & 0.48 & 0.13 & 0.16 & 0.22 & 0.21 & 0.25 & 0.33 \\
\hline upport & 0.28 & 0.33 & 0.31 & 0.27 & 0.33 & 0.31 & 0.28 & 0.33 & 0.43 & 0.12 & 0.14 & 0.19 & 0.18 & 0.22 & 0.29 & 0.16 & 0.19 & 0.26 \\
\hline & .10 & 0.12 & 12 & \begin{tabular}{|l|}
0.12 \\
\end{tabular} & 0.15 & 14 & 15 & & 1.24 & .10 & .12 & .11 & 1 & .16 & .2 & .18 & 0.2 & .20 \\
\hline
\end{tabular}

Source: Authors' own processing

The results indicate a weak or very weak link between the assessment of the quality characteristics of management accounting reports and the company profile, in both countries. A moderate dependence can be identified in few cases, such as the relationship between the relevance of the report and the origin of the capital, or the IT support and the company size in Poland, respectively between the report comments and the company size, or the degree of detail and the origin of the capital in Romania.

The manager profile proved to determine managers' assessment of the management accounting reports to a weak or very weak extent (see Table no. 11).

\section{Table no. 11. The relationship between the manager profile and the assessment of the quality characteristics of MA reports}

\begin{tabular}{|c|c|c|c|c|c|c|c|c|c|c|c|c|c|c|c|c|c|c|}
\hline \multirow{3}{*}{$\begin{array}{c}\text { Manager profile } \\
\text { Country } \\
\text { Coefficient }\end{array}$} & \multicolumn{6}{|c|}{ Professional exeprience } & \multicolumn{6}{|c|}{ Education } & \multicolumn{6}{|c|}{ Managed department } \\
\hline & \multicolumn{3}{|c|}{ POL } & \multicolumn{3}{|c|}{ ROM } & \multicolumn{3}{|c|}{ POL } & \multicolumn{3}{|c|}{ ROM } & \multicolumn{3}{|c|}{ POL } & \multicolumn{3}{|c|}{ ROM } \\
\hline & Tc & $\mathrm{V}_{\mathrm{c}}$ & $C_{P}$ & Tc & $\mathrm{V}_{\mathrm{c}}$ & $C_{P}$ & Tc & $\mathrm{V}_{\mathrm{c}}$ & $C_{P}$ & Tc & $\mathrm{V}_{\mathrm{c}}$ & $C_{P}$ & Tc & $\mathbf{V}_{\mathrm{c}}$ & $C_{P}$ & Tc & $\mathrm{V}_{\mathrm{c}}$ & $C_{p}$ \\
\hline omprehensibility & & 0.14 & & 0.22 & 0.27 & 0.35 & 0.20 & 0.23 & 0.23 & 0.11 & 0.13 & 0.13 & 0.18 & 0.26 & 0.35 & 0.20 & 0.29 & 0.38 \\
\hline omp & & & 0.24 & 0.22 & & 0.34 & 0.15 & & & 0.34 & & 0.41 & & & 0.37 & & & 0.29 \\
\hline larit & & & 0.14 & & & & & & 0.19 & 0.11 & & & & & 0.32 & & & .28 \\
\hline & & & 0.26 & & & & & & & & & & & & 0.3 & & & 0.25 \\
\hline & & & 0. & & & & & & & & & & & & 0.26 & 0.20 & & 0.37 \\
\hline & 0.12 & 0.14 & 0.19 & 0.25 & 0.30 & 0.32 & 0.04 & 0.04 & 0.04 & 0.42 & 0.50 & 0.48 & 0.16 & 0.23 & 0.31 & 0.14 & 0.23 & 0.31 \\
\hline Graph & & & 0.20 & & & & & & 0.33 & 0.32 & & & & & 0.27 & 0.22 & & 0.41 \\
\hline eleva & 0.08 & 0.09 & 0.13 & 0.14 & 0.17 & 0.24 & 0.12 & 0.15 & 0.15 & 0.13 & 0.16 & 0.16 & 0.19 & 0.27 & 0.36 & 0.17 & 0.25 & 0.33 \\
\hline Comments on $\mathrm{t}$ & 0.18 & 0.21 & 0.28 & 0.24 & 0.29 & 0.38 & 0.11 & 0.13 & 0.13 & 0.15 & 0.18 & 0.17 & 0.14 & 0.20 & 0.27 & 0.18 & 0.27 & 0.35 \\
\hline IT support & 0.12 & 0.15 & 0.20 & 0.12 & 0.14 & 0.20 & 0.16 & 0.19 & 0.18 & 0.28 & 0.34 & 0.32 & 0.16 & 0.24 & 0.32 & 0.30 & 0.43 & 0.52 \\
\hline ierence to & 0.26 & 0.31 & 0.40 & \begin{tabular}{|l|}
0.18 \\
\end{tabular} & 0.21 & 0.29 & 0.15 & \begin{tabular}{|l|}
0.17 \\
\end{tabular} & \begin{tabular}{|l|}
0.17 \\
\end{tabular} & \begin{tabular}{|l|}
0.07 \\
\end{tabular} & $\mid 0.09$ & 0.09 & 0.18 & 0.26 & 0.34 & $\mid 0.11$ & 0.16 & 0.22 \\
\hline
\end{tabular}

Source: Authors' own processing 
The work experience of the managers is linked in Poland to the assessment concerning the reference to future of the information provided in the reports, and in Romania to the assessment of the report clarity. Moderate relationships are further observed in Romania between the education of the managers and the assessment of the report completeness and comparability, as well as between the managed department and the IT support and graphical presentation.

As for the operations of the management accounting department, as the third examined variable, it proved to determine the specific assessments to a weak or very weak extent (see Table no. 12).

\section{Table no. 12. The relationship between the operations of the MA department and the assessment of the quality characteristics of MA reports}

\begin{tabular}{|c|c|c|c|c|c|c|c|c|c|c|c|c|c|c|c|c|c|c|}
\hline \multirow{3}{*}{$\begin{array}{c}\begin{array}{c}\text { Operations of the MA } \\
\text { department }\end{array} \\
\text { Country } \\
\text { Coefficient }\end{array}$} & \multicolumn{6}{|c|}{ Organisation of MA } & \multicolumn{6}{|c|}{ Frequency of reporting } & \multicolumn{6}{|c|}{ Frequency of meetings } \\
\hline & \multicolumn{3}{|c|}{ POL } & \multicolumn{3}{|c|}{ ROM } & \multicolumn{3}{|c|}{ POL } & \multicolumn{3}{|c|}{ ROM } & \multicolumn{3}{|c|}{ POL } & \multicolumn{3}{|c|}{ ROM } \\
\hline & $T_{c}$ & $\mathrm{~V}_{\mathrm{c}}$ & $C_{p}$ & $T_{c}$ & $V_{c}$ & $C_{p}$ & $T_{c}$ & $\mathrm{~V}_{\mathrm{c}}$ & $C_{P}$ & $T_{c}$ & $\mathrm{~V}_{\mathrm{c}}$ & $C_{p}$ & $T_{c}$ & $\mathrm{~V}_{\mathrm{c}}$ & $C_{p}$ & $T_{c}$ & $V_{c}$ & $C_{p}$ \\
\hline Comprehensibility & 0.12 & 0.15 & 0.14 & 0.12 & 0.14 & 0.14 & 0.20 & 0.23 & 0.31 & 0.17 & 0.21 & 0.28 & 0.15 & 0.18 & 0.24 & 0.28 & 0.33 & 0.43 \\
\hline Compl & & & 0.10 & 0. & 0.2 & 0.22 & 0.19 & & 31 & 14 & 17 & 0.23 & 0.16 & 0.20 & 27[ & 0.20 & & \\
\hline & & & & & & & & & 0.37 & & & & & & 0.31 & & & \\
\hline & & & & & & 0.2 & & & 0. & & & 0. & & & 0.27 & & & \\
\hline & & & 0.23 & & & 0.14 & 0.13 & & 0.21 & & & 0.23 & 0.1 & & 0.25 & 0.27 & & \\
\hline $\begin{array}{l}\text { Comp } \\
\text { (stand }\end{array}$ & 0.21 & 0.25 & 0.24 & 0.24 & 0.29 & 0.28 & 0.13 & 0.15 & 0.21 & 0.08 & 0.10 & 0.16 & 0.13 & 0.16 & 0.22 & 0.16 & 0.19 & $0.2^{2}$ \\
\hline Graph & & & & & & 0.28 & & & 0.29 & & & 0.32 & & & 0.26 & 0.13 & & 0.22 \\
\hline Relevance & 0.14 & 0.16 & 0.16 & 0.12 & 0.15 & 0.15 & 0.13 & 0.15 & 0.21 & 0.23 & 0.28 & 0.36 & 0.16 & 0.19 & 0.26 & 0.24 & 29 & 0.3 \\
\hline Commer & 0.10 & 0.11 & 0.11 & 0.26 & 0.31 & 0.29 & 0.16 & 0.19 & 0.26 & 0.23 & 0.27 & 0.36 & 0.18 & 0.22 & 0.29 & 0.25 & 0.30 & 0.39 \\
\hline IT supp & 0.14 & 0.17 & 0.16 & 0.21 & 0.25 & 0.24 & 0.28 & 0.34 & 0.43 & 0.18 & 0.22 & 0.30 & 0.17 & 0.20 & 0.28 & 0.23 & 0.28 & 0.36 \\
\hline Reference to future & 0.25 & 0.29 & 0.28 & 0.29 & 0.34 & 0.32 & 0.17 & 0.20 & 0.27 & 0.15 & 0.17 & 0.24 & 0.16 & 0.19 & \begin{tabular}{|l|}
0.26 \\
\end{tabular} & 0.30 & 0.35 & 0.45 \\
\hline
\end{tabular}

Source: Authors' own processing

Neither the organisation of the management accounting department nor the reporting frequency are linked to the assessment of the quality characteristics of internal reports, except for a moderate relationship between the latter and the reporting IT support, in the case of Poland. In Romania, the frequency of meetings between managers and management accountants is, however, a relevant factor for the quality assessment of internal reports, based on the moderate relationship between the considered variable, and the assessment of the clarity, comprehensibility, degree of detail and reference to future.

\subsection{Factors determining the managers' assessment of the communication channel of the information provided by the management accounting department}

In order to identify the factors determining the assessment of different communication channels of the information provided by the management accounting department, we relied on the correlation between this specific assessment and the same three variables employed in the prior analyses: the company profile, the manager profile and the operations of the management accounting department.

Out of these, the company profile doesn't interact significantly with the assessment of the considered communication channels (see Table no. 13). 
Table no. 13. The relationship between the company profile and the assessment of the communication channel of the information provided by the MA department

\begin{tabular}{|c|c|c|c|c|c|c|c|c|c|c|c|c|c|c|c|c|c|c|}
\hline \multirow{3}{*}{$\begin{array}{c}\text { Company profile } \\
\text { Country } \\
\text { Coefficient }\end{array}$} & \multicolumn{6}{|c|}{ Type of the company } & \multicolumn{6}{|c|}{ Size of the company } & \multicolumn{6}{|c|}{ Origin of the capital } \\
\hline & \multicolumn{3}{|c|}{ POL } & \multicolumn{3}{|c|}{ ROM } & \multicolumn{3}{|c|}{ POL } & \multicolumn{3}{|c|}{ ROM } & \multicolumn{3}{|c|}{ POL } & \multicolumn{3}{|c|}{ ROM } \\
\hline & $\mathrm{T}_{\mathrm{c}}$ & $\mathbf{V}_{\mathrm{c}}$ & $C_{P}$ & $\mathrm{~T}_{\mathrm{c}}$ & $\mathbf{V}_{\mathrm{c}}$ & $C_{p}$ & $\mathrm{~T}_{\mathrm{c}}$ & $V_{c}$ & $C_{p}$ & $\mathrm{~T}_{\mathrm{c}}$ & $V_{c}$ & $C_{p}$ & $T_{c}$ & $\mathbf{V}_{\mathrm{c}}$ & $C_{p}$ & $T_{c}$ & $\mathbf{V}_{\mathrm{c}}$ & $C_{p}$ \\
\hline PDF files & 0.07 & 0.09 & 0.09 & 0.13 & 0.14 & 0.15 & 0.18 & 0.22 & 0.29 & 0.15 & 0.18 & 0.25 & 0.09 & 0.10 & 0.15 & 0.18 & 0.22 & 0.29 \\
\hline Printed version & 0.12 & 0.14 & 0.14 & 0.18 & 0.21 & 0.20 & 0.15 & 0.18 & 0.25 & 0.32 & 0.39 & 0.48 & 0.18 & 0.21 & 0.29 & 0.20 & 0.24 & 0.3 \\
\hline Excel data tra & 0.27 & 0.32 & 0.31 & 0.12 & 0.15 & 0.14 & 0.18 & 0.21 & 0.29 & 0.08 & 0.13 & 0.13 & 0.13 & 0.16 & 0.22 & 0.12 & 0.20 & 0.15 \\
\hline Online via Frontend & 0.22 & 0.26 & 0.25 & 0.07 & 0.09 & 0.08 & 0.21 & 0.25 & 0.34 & 0.33 & 0.49 & 0.40 & 0.23 & 0.27 & 0.36 & 0.30 & 0.45 & 0.35 \\
\hline Mobile reporting & 0.07 & 0.08 & 0.08 & 0.15 & 0.18 & 0.18 & 0.23 & 0.28 & 0.37 & 0.29 & 0.35 & 0.44 & 0.13 & 0.16 & 0.22 & 0.21 & 0.25 & 0.34 \\
\hline
\end{tabular}

Source: Authors' own processing

The few moderate relationships that can be observed originate exclusively from Romania, where the company size is linked to the delivery of specific information through mobile reporting or online data whereas both communication channels are employed rather by large companies, as well as through printed reports - frequently used by smaller companies. A third moderate relationship is exhibited between the origin of the capital and the online communication of the data - a common channel in companies with foreign capital, due to the high geographic spread of the companies within a group.

In the same line, only a very weak relationship can be observed between the manager profile and the assessment of the communication channel (see Table no. 14).

\section{Table no. 14. The relationship between the manager profile and the assessment of the communication channel of the information provided by the MA department}

\begin{tabular}{|c|c|c|c|c|c|c|c|c|c|c|c|c|c|c|c|c|c|c|}
\hline \multirow{3}{*}{$\begin{array}{c}\text { Manager profile } \\
\text { Country } \\
\text { Coefficient }\end{array}$} & \multicolumn{6}{|c|}{ Professional exeprience } & \multicolumn{6}{|c|}{ Education } & \multicolumn{6}{|c|}{ Managed department } \\
\hline & \multicolumn{3}{|c|}{ POL } & \multicolumn{3}{|c|}{ ROM } & \multicolumn{3}{|c|}{ POL } & \multicolumn{3}{|c|}{ ROM } & \multicolumn{3}{|c|}{ POL } & \multicolumn{3}{|c|}{ ROM } \\
\hline & $T_{c}$ & $\mathbf{V}_{\mathrm{c}}$ & $C_{P}$ & $\mathrm{~T}_{\mathrm{c}}$ & $V_{c}$ & $C_{p}$ & $T_{c}$ & $V_{c}$ & $C_{P}$ & $T_{c}$ & $\mathrm{~V}_{\mathrm{c}}$ & $C_{p}$ & $\mathrm{~T}_{\mathrm{c}}$ & $V_{c}$ & $C_{p}$ & $\mathrm{~T}_{\mathrm{c}}$ & $\mathbf{V}_{\mathrm{c}}$ & $C_{P}$ \\
\hline PDF files & 0.17 & 0.20 & 0.28 & 0.18 & 0.21 & 0.29 & 0.15 & 0.17 & 0.17 & 0.08 & 0.09 & 0.09 & 0.17 & 0.24 & 0.32 & 0.19 & 0.27 & 0.36 \\
\hline Printed version reports & 0.24 & 0.29 & 0.38 & 0.27 & 0.32 & 0.42 & 0.30 & 0.36 & 0.34 & 0.17 & 0.20 & 0.21 & 0.16 & 0.23 & 0.30 & 0.22 & 0.32 & 0.41 \\
\hline Excel data transfer & 0.21 & 0.25 & 0.34 & 0.11 & 0.19 & 0.18 & 0.01 & 0.02 & 0.02 & 0.07 & 0.09 & 0.09 & 0.15 & 0.22 & 0.30 & 0.10 & 0.21 & 0.20 \\
\hline Online via Frontend & 0.07 & 0.08 & 0.12 & 0.18 & 0.21 & 0.28 & 0.11 & 0.13 & 0.13 & 0.15 & 0.18 & 0.17 & 0.17 & 0.24 & 0.33 & 0.14 & 0.21 & 0.28 \\
\hline Mobile reporting & 0.10 & 0.12 & 0.17 & 0.17 & 0.20 & 0.27 & 0.17 & 0.20 & 0.20 & 0.09 & 0.10 & 0.10 & 0.13 & 0.19 & 0.26 & 0.19 & 0.28 & 0.37 \\
\hline
\end{tabular}

Source: Authors' own processing

Merely two moderate relationships can be identified at this point, both originating from Romania and involving the employment of printed reports, in connection with the work experience of the manager, respectively with the managed department.

The last examined factor, i.e. the operations of the management accounting department, is proven to determine the specific assessments to a very weak extent (see Table no. 15)
The only moderate relationship is observed between the frequency of reporting and the employment of mobile reporting in the case of Romania. This is a justified relationship as the large share of branch offices in Romania requires the use of advanced IT solutions, like mobile reporting. In all the other examined instances, the relationships are very weak or weak and thus are not subject to further interpretation. 


\begin{tabular}{|c|c|c|c|c|c|c|c|c|c|c|c|c|c|c|c|c|c|c|}
\hline \multirow{3}{*}{$\begin{array}{c}\begin{array}{c}\text { Operations of the MA } \\
\text { department }\end{array} \\
\text { Country } \\
\text { Coefficient } \\
\end{array}$} & \multicolumn{6}{|c|}{ Organisation of MA } & \multicolumn{6}{|c|}{ Frequency of reporting } & \multicolumn{6}{|c|}{ Frequency of meetings } \\
\hline & \multicolumn{3}{|c|}{ POL } & \multicolumn{3}{|c|}{ ROM } & \multicolumn{3}{|c|}{ POL } & \multicolumn{3}{|c|}{ ROM } & \multicolumn{3}{|c|}{ POL } & \multicolumn{3}{|c|}{ ROM } \\
\hline & $T_{c}$ & $\mathrm{~V}_{\mathrm{c}}$ & $C_{p}$ & $T_{c}$ & $\mathrm{~V}_{\mathrm{c}}$ & $C_{p}$ & $T_{c}$ & $\mathrm{~V}_{\mathrm{c}}$ & $C_{p}$ & $T_{c}$ & $\mathrm{~V}_{\mathrm{c}}$ & $C_{p}$ & $T_{c}$ & $\mathrm{~V}_{\mathrm{c}}$ & $C_{p}$ & $T_{c}$ & $\mathrm{~V}_{\mathrm{c}}$ & $C_{p}$ \\
\hline PDF files & 0.23 & 0.28 & 0.27 & 0.12 & 0.14 & 0.14 & 0.11 & 0.13 & 0.19 & 0.20 & 0.23 & 0.31 & 0.22 & 0.26 & 0.35 & 0.23 & 0.27 & 0.36 \\
\hline Printed version reports & 0.32 & 0.38 & 0.35 & 0.23 & 0.27 & 0.26 & 0.08 & 0.10 & 0.14 & 0.19 & 0.23 & 0.30 & 0.19 & 0.23 & 0.31 & 0.24 & 0.29 & 0.38 \\
\hline Excel data transfer & 0.14 & 0.17 & 0.17 & 0.12 & 0.14 & 0.14 & 0.15 & 0.18 & 0.25 & 0.12 & 0.21 & 0.20 & 0.16 & 0.19 & 0.26 & 0.20 & 0.34 & 0.32 \\
\hline Online via Frontend & 0.23 & 0.27 & 0.26 & 0.14 & 0.16 & 0.16 & 0.11 & 0.13 & 0.18 & 0.23 & 0.28 & 0.37 & 0.11 & 0.13 & 0.18 & 0.16 & 0.19 & 0.26 \\
\hline Mobile reporting & 0.17 & 0.21 & 0.20 & 0.22 & 0.26 & 0.25 & 0.18 & 0.22 & 0.29 & 0.28 & 0.33 & 0.43 & 0.15 & 0.18 & 0.25 & 0.23 & 0.27 & 0.36 \\
\hline
\end{tabular}

Source: Authors' own processing

\section{Conclusions}

There is a global homogenization tendency in matters of management accounting practices, though research often points to particularities of American, Western European and Japanese management accounting practices (Chow et al., 1994; Granlund and Lukka, 1998, Horvath, 2011), as well as to specific features of management accounting practices in Central and Eastern European countries, with a similar historical background (Szychta, 2008).

In this context, the objective of the present paper was to test the strength of the relationship between selected variables and the managers' assessment of the information provided by the management accounting system. For this purpose, we employed the correlation analysis based on Czuprow's $T$ coefficient - $T_{c}$, Pearson's C coefficient - $C_{p}$ and Cramer's V coefficient $V_{c}$, applied to data collected from randomly selected companies located in Poland and Romania.

The correlation coefficients employed in the study revealed, in case of both Poland and Romania, a rather weak relationship between the three selected organizational variables - the company profile, the manager profile and the operations of the management accounting department - on the one hand, and the assessed suitability of management accounting information and reporting, on the other hand (see Appendix).

The company profile is a factor with a weak to moderate influence on the assessed suitability of the information derived from the management accounting system by Polish and Romanian managers. Regardless of the type of company, its size and the origin of the capital, the managers' assessments are mainly similar. There are few exceptions to this matter, like the moderate relationship between the company type and the assessed suitability of the information for R\&D decisions in Romania. The importance of the company profile, mainly of the origin of the capital, has also been emphasized in literature (Gordon and Miller, 1976; Waterhouse and Tiessen, 1978; Macintosh and Draft, 1987).

The manager profile proves to be weakly and moderately connected to the assessed suitability of the information derived from the management accounting system, whereas most moderate relationships are observed around the managed department of the respondent, especially in the case of Romania.

In respect of the third factor - the operations of the management accounting department - the strongest relationships were observed between the frequency of the meetings between managers and management accountants, on the one hand, and the assessed suitability of the information provided by management accounting, on the other hand.

The study contributes to the body of related research in two senses: it identifies influencing factors of the manner in which managers assess the usefulness of the information provided by management accounting, and it provides a comparison in the matter of interest between two Eastern European countries where, to the best of our knowledge, no similar study has been conducted. As limits of the research, we should first point to the unbalanced distribution of the responses received in Poland and Romania, leading to the fact that the 
comparison can't be generalised. Second, the managers' perception was examined only based on questionnaires. The results need be further substantiated based on interviews performed among the same respondents.

Starting from the results of the present study, we can identify two future research directions: (a) a macro-level analysis of cultural factors that might influence the managers' perceptions on the suitability of the information provided by the MAS for the managerial process and (b) a comparative analysis based on contingency variables, with a similar scope, between the managers' perceptions within the CEE countries and other countries, particularly the Western ones.

\section{REFERENCES}

1. Abernethy, M.A. and Guthrie, C.H. (1994), An empirical assessment of the "fit" between strategy and management information system design, Accounting and Finance, vol. 34, no. 2, pp. 49-66, DOI 10.1111/j.1467-629x.1994.tb00269.x.

2. Ahrenes, T. (1996), Styles of accountability, Accounting, Organizations and Society, vol. 21, no. 2-3, pp. 139-173, DOI 10.1016/0361-3682(95)00052-6.

3. Albu, N. and Albu, C.N. (2012), Factors associated with the adoption and use of management accounting techniques in developing countries: The case of Romania, Journal of International Financial Management and Accounting, vol. 23, no. 3, pp. 245-276, DOI 10.1111/jifm. 12002.

4. Anderson, S.W. and Lanen, W.N. (1999), Economic transition, strategy and the evolution of management accounting practices: the case of india, Accounting, Organizations and Society, vol. 24, no. 5-6, pp. 379-412, DOI 10.1016/s0361-3682(97)00060-3.

5. Aver, B. and Cadez, S. (2009), Management accountants' participation in strategic management processes: A cross industry comparison, Journal of East European Management Studies, vol. 14, no. 3, pp. 310-322.

6. Baiman, S. (1982), Agency research in managerial accounting: a survey, Journal of Accounting Literature, vol. 1, pp. 154-213.

7. Bergsma, W. (2013), A bias correction for Cramer's $\mathrm{V}$ and Tschuprow's T, Journal of the Korean Statistical Society, vol. 42, no. 3, pp. 323-328, DOI 10.1016/j.jkss.2012.10.002.

8. Blum, H.S. (2006), Logistik-Controlling, Kontext, Ausgestaltung und Erfolgswirkungen (chapter 5), Wiesbade, Deutscher Universitats-Verlag.
9. Brownell, P. (1982), Participation in the budgeting process: When it works and when it doesn't, Journal of Accounting Literature, vol. 1, pp. 124-153.

10. Brownell, P. and Hirst, M.K. (1986), Reliance on accounting information, budgetary participation and task uncertainty: Tests of a three-way interaction, Journal of Accounting Research, vol. 24, no. 2, pp. 241-249, DOI 10.2307/2491132.

11. Bruns, W.J. and Waterhouse, J. (1975), Budgetary control and organizational structure, Journal of Accounting Research, vol. 13, no. 2, pp. 177-203, DOI 10.2307/2490360.

12. Budde, J. (2009), Variance analysis and linear contracts in agencies with distorted performance measures, Management Accounting Research, vol. 20, no. 3, pp. 166-176, DOI 10.1016/j.mar.2008.12.002.

13. Burns, T. and Stalker, G.M. (1967), The Management of Innovation, London, Tavistock.

14. Burns, W.J. and McKinnon, S.M. (1992a): Management information and accounting information: what do managers want? In Advances in Management Accounting, Epstein M.J. (ed.), vol. 1, pp. 55-80, Greenwich: Jail Press Inc.

15. Burns, W.J. and McKinnon, S.M. (1992b), The Information Mosaic, Boston, Harvard Business School Press.

16. Burns, W.J. and McKinnon, S.M. (1993), Information and managers: a field study, Journal of Management Accounting Research, vol. 5, pp. 84-108.

17. Cadez, S. and Guilding, C. (2008), An exploratory investigation of an integrated contingency model of strategic management accounting, Accounting, Organizations and Society, vol. 33, no. 7-8, pp. 836-863, DOI 10.1016/j.aos.2008.01.003. 
18. Chapmann, C.S. (1997), Reflections on a contingent view of accounting, Accounting, Organizations and Society, vol. 22, no. 2, pp. 189205, DOI 10.1016/s0361-3682(97)00001-9.

19. Cheffi, W. and Beldi, A. (2012), Analysis of managers' use of management accounting, International Journal of Business, vol. 17, no. 2 , pp. 113-125.

20. Chenhall, R.H (2007): Theorizing contingencies in management control systems research. In Handbooks of Management Accounting Research, Chapman, C.S., Hopwood, A.G., Shields, M.D. (Eds.), pp. 163-205, Elsevier, DOI 10.1016/s1751-3243(06)01006-6.

21. Chenhall, R.H. (2003), Management control systems design within its organizational context: Findings from contingency-based research and directions for the future, Accounting, Organizations and. Society, vol. 28, no. 2-3, pp. 127-168, DOI 10.1016/s0361-3682(01)00027-7.

22. Chenhall, R.H. and Morris, D. (1986), The impact of structure, environment and interdependence on the perceived usefulness of management accounting systems, The Accounting Review, vol. 61, no. 1, pp. 16-35.

23. Chong, V.K. (1996), Management accounting systems, task uncertainty and managerial performance: A research note, Accounting, Organizations and Society, vol. 21, no. 5, pp. 415421, DOI 10.1016/0361-3682(95)00045-3.

24. Chow, C.W., Kato, Y. and Shields, M.D. (1994), National culture and the preference for management controls: An exploratory study of the firm - labor market interface, Accounting, Organizations and Society, vol. 19, no. 4-5, pp. 381-400, DOI 10.1016/0361-3682(94)90003-5.

25. Dropulic, I. (2013), The effect of contingency factors on management control systems: a study of manufacturing companies in Croatia, Economic Research, vol. 26, special issue 1, pp. 369-382, DOI 10.1080/1331677x.2013.11517657.

26. Dunk, A.S. (1992), Reliance on budgetary control, manufacturing process automation and production sub-unit performance: a research note, Accounting, Organizations and Society, vol. 17, no. 3-4, pp. 195-203, DOI 10.1016/0361-3682(92)90020-s.

27. Emmanuel, C., Otley, D. and Merchant, K. (1990), Accounting for Management Control, $2^{\text {nd }}$ edition,
London: Chapman \& Hall, DOI 10.1007/978-14899-6952-1.

28. Fisher, C. (1996), The impact of perceived environmental uncertainty and individual differences on management information requirements: a research note, Accounting, Organizations and Society, vol. 21, no. 4, pp. 361-369, DOI 10.1016/0361-3682(95)00029-1.

29. Fisher, J. (1995), Contingency-based research on management control systems: categorization by level of complexity, Journal of Accounting Literature, vol. 14, pp. 24-53.

30. Gordon, L.A. and Miller, D.A. (1976), A contingency framework for the design of accounting information systems, Accounting, Organizations and Society, vol. 1, no. 1, pp. 56-69, DOI 10.1016/0361-3682(76)90007-6.

31. Gordon, L.A. and Narayanan, V.K. (1984), Management accounting systems, perceived environmental uncertainty and organization structure: An empirical investigation, Accounting, Organizations and Society, vol. 9, no. 2, pp. 33-47, DOI 10.1016/0361-3682(84)90028-x.

32. Granlund, M. and Lukka, K. (1998), It's a small world of management accounting practices, Journal of Management Accounting Research, vol. 10, pp. 153-176.

33. Gul, F.A. (1991), The effects of management accounting systems and environmental uncertainty on small business managers' performance, Accounting and Business Research, vol. 22, no. 85, pp. 57-61, DOI 10.1080/00014788.1991.9729418.

34. Gul, F.A. and Chia, Y.M. (1994), The effects of management accounting systems, perceived environmental uncertainty and decentralization on managerial performance: A test of three-way interaction, Accounting, Organizations and Society, vol. 19 , no.4-5, pp. 413-426, DOI 10.1016/0361-3682(94)90005-1.

35. Gupta, A.K. and Govindarajan, V. (1984), Business unit strategy, managerial characteristics, and business unit effectiveness at strategy implementation, Academy of Management Journal, vol. 27, no. 1, pp. 25-41, DOI 10.2307/255955.

36. Gupta, A.K. and Govindarajan, V. (1991), Knowledge flows and the structure of control within multinational corporations, Academy of 
Management Review, vol. 16, no. 4, pp. 768-792, DOI 10.5465/amr.1991.4279628.

37. Haldma, T. and Laats, K. (2002), Contingencies influencing management accounting practices of Estonian manufacturing companies, Management Accounting Research, vol. 13, no. 4, pp. 379-400, DOI 10.1006/mare.2002.0197.

38. Hambrick, D.C. and Lei, D. (1985), Toward an empirical prioritization of contingency variables for business strategy, Academy of Management Journal, vol. 28, no. 4, pp. 763-788, DOI $10.2307 / 256236$.

39. Harrison, G.L. (1992), The cross-cultural generalizability of the relation between participation, budget emphasis and job-related attitudes, Accounting, Organizations and Society, vol. 17, no. 1, pp. 1-15,

DOI 10.1016/0361-3682(92)90033-0.

40. Hartmann, F. (2000), The appropriateness of RAPM: towards the further development of theory, Accounting, Organizations and Society, vol. 25, no. 4-5, pp. 451-482, DOI 10.1016/s0361-3682(98)00036-1.

41. Hofstede, G.H. (1967), The Game of Budget Control, London: Tavistock.

42. Hofstede, G.H. (1980), Culture's Consequences: International Differences in Work-related Values, Los Angeles: Sage Publications.

43. Hofstede, G.H. (1983), The cultural relativity of organizational practices and theories, Journal of International Business Studies, vol. 14, no. 2, pp. 75-89, DOI 10.1057/palgrave.jibs.8490867.

44. Hofstede, G.H. (1984), The cultural relativity of the quality of life concept, Academy of Management Review, vol. 9, no. 3, pp. 389-398, DOI 10.2307/258280.

45. Hofstede, G.H., Hofstede, G.J. and Minkov, M. (2010), Culture and Organizations: software of the mind, $3^{\text {rd }}$ edition, New York: McGraw-Hill.

46. Hopper, T., Tsamenyi, M., Uddin, S. and Wickramasinghe, D. (2009), Management accounting in less developed countries: what is known and needs knowing, Accounting, Auditing \& Accountability Journal, vol. 22, no. 3, pp. 469-514, DOI 10.1108/09513570910945697.

47. Hopwood, A.G. (1972), The relationship between accounting and personnel management - past conflicts and future potential, Personnel Review, vol. 1, issue 2, pp. 40-47, DOl 10.1108/eb055199.

48. Horvath, P. (2011), Controlling, 12. Aufgabe, München: Verlag Vahlen.

49. Islam, J. and Hu, H. (2012), A literature review on contingency theory in managerial accounting, African Journal of Business Management, vol. 6 , no. 15, pp. 5159-5164, DOI 10.5897/ajbm11.2764.

50. Jaruga, A. and Ho, S.S.M. (2002), Management accounting in transitional economies, Management Accounting Research, vol. 13, no. 4, pp. 375-378, DOI 10.1006/mare.2002.0196.

51. Johnson, H.T. and Kaplan, R.S. (1987), Relevance Lost, Boston: Harvard Business School Press.

52. Keller, G. (2012), Managerial Statistics, Boston: South-Western Cengage Learning.

53. Khandwalla, P. (1972), The effects of different types of competition on the use of management controls, Journal of Accounting Research, vol. 10, no. 2, pp. 275-295, DOI 10.2307/2490009.

54. Khandwalla, P. (1977), Design of organisations, New York: Harcourt Brace Jovanovich.

55. Klassen, M. (2014), Value logics and management control systems. PhD Thesis. Lancaster University, UK.

56. Lawrence, P. and Lorsch, J. (1967), Organization and Environment, Irwin: Homewood.

57. Luft, J. and Shields, M.D. (2002), Zimmerman's contentious conjectures: describing the present and prescribing the future of empirical management accounting research, European Accounting Review, vol. 11, no. 4, pp. 795-803, DOI 10.1080/0963818022000047091.

58. Luther, R.G. and Longden, S. (2001), Management accounting in companies adapting to structural change and volatility in transition economies: a South African study, Management Accounting Research, vol. 12, no. 3, pp. 299-320, DOI 10.1006/mare.2001.0163.

59. Macintosh, N.B. and Daft, R.L. (1987), Management control systems and departmental interdependencies: an empirical study, Accounting, Organizations and Society, vol. 12, no. 1, pp. 4961, DOI 10.1016/0361-3682(87)90015-8.

60. Malmi, T. and Granlund, M. (2009), In search of management accounting theory, European 
Accounting Review, vol. 18, no. 3, pp. 597-620, DOI 10.1080/09638180902863779.

61. Mendoza, C. and Bescos, P.L. (2001) An explanatory model of managers' information needs: implications for management accounting, The European Accounting Review, vol. 10, no. 2, pp. 257-289, DOI 10.1080/09638180126636.

62. Merchant, K.A. (1981), The design of the corporate budgeting system: influences on managerial behaviour and performance, The Accounting Review, vol. 56, no. 4, pp. 813-829.

63. Merchant, K.A. (1984), Influences on departmental budgeting: an empirical examination of a contingency model, Accounting, Organizations and Society, vol. 9, no. 3-4, pp. 291-307, DOI 10.1016/0361-3682(84)90013-8.

64. Merchant, K.A. (1985), Budgeting and the propensity to create budgetary slack, Accounting, Organizations and Society, vol. 10, no. 2, pp. 201210, DOI 10.1016/0361-3682(85)90016-9.

65. Merchant, K.A. (1990), The effects of financial controls on data manipulation and management Myopia, Accounting, Organizations and Society, vol. 15, no. 4, pp. 297-313, DOI 10.1016/03613682(90)90021-।.

66. Merchant, K.A. (1998), Modern Management Control Systems. Text and Cases, Upper Saddle River: Prentice Hall.

67. Miles, R.W. and Snow, C.C. (1978), Organizational strategy, structure and process, New York: McGraw-Hill.

68. Mockler, R.J. (2002), Multinational Strategic Management: An Integrative Entrepreneurial Context-Specific Process, New York: International Business Press.

69. Nita, B. (2009), Rola rachunkowości zarządczej we wspomaganiu zarządzania dokonaniami przedsiębior-stwa, Wrocław: Uniwersytet Ekonomiczny we Wrockawiu.

70. Nita, B. (2013), Teoria uwarunkowań sytuacyjnych w rachunkowości zarządczej, Zeszyty Teoretyczne Rachunkowości, no.71(127), pp. 193-209, DOI 10.5604/16414381.1061656.

71. O'Connor, N. (1995), The influence of organizational culture on the usefulness of budget participation by Singaporean-Chinese managers, Accounting, Organization and Society, vol. 20, no. 5 , pp. 383-403,

DOI 10.1016/0361-3682(94)00034-s.

72. Otley, D.T. (1978), Budget use and managerial performance, Journal of Accounting Research, vol. 16, no. 1, pp. 122-149, DOI 10.2307/2490414.

73. Otley, D.T. (1980), The contingency theory of management accounting: Achievement and prognosis, Accounting, Organizations and Society, vol. 5, no. 4, pp. 413-428, DOI 10.1016/0361-3682(80)90040-9.

74. Otley, D.T. (2016), The contingency theory of management accounting and control: 1980-2014, Management Accounting Research, vol. 31, pp. 45-62, DOI 10.1016/j.mar.2016.02.001.

75. Pierce, B. and O'Dea, T. (2003), Management accounting information and the needs of managers. Perceptions of managers and accountants compared, British Accounting Review, vol. 35, no. 3, pp. 257-290,

DOI 10.1016/s0890-8389(03)00029-5.

76. Sharma, D.S. (2002), The differential effect of environmental dimensionality, size, and structure on budget system characteristics in hotels, Management Accounting Research, vol. 13, no. 1, pp. 101-130, DOI 10.1006/mare.2002.0183.

77. Simons, R. (1987), Accounting control systems and business strategy: an empirical analysis, Accounting, Organizations and Society, vol. 12, no. 4, pp. 357-374, DOI 10.1016/0361-3682(87)90024-9.

78. Sobczyk, M. (2000), Statystyka, Warsaw: PWN.

79. Subramaniam, N. (1993), A managerial perspective on management accounting system adequacy gap, Accounting and Finance, vol. 17, no. 2, pp. 19-37.

80. Szychta, A. (2002), The scope of application of management accounting methods in Polish enterprises, Management Accounting Research, vol. 13, no. 4, pp. 401-418, DOI 10.1006/mare.2002.0198.

81. Szychta, A. (2008), Procesowe ukierunkowanie współczesnej rachunkowości zarządczej, Zeszyty Teoretyczne Rachunkowości, no. 44, pp. 91-100.

82. Waterhouse, J.H. and Tiessen, P. (1978), A contingency framework for management accounting systems research, Accounting, Organizations and Society, vol. 3, no. 1, pp. 65-76, DOI 10.1016/0361-3682(78)90007-7. 
83. Waveru, N.M. (2010), The origin and evolution of management accounting: a review of the theoretical framework, Problems and Perspectives in Management, vol. 8, no. 3, pp. 165-182.

84. Woods, M. (2009), A contingency theory perspective on the risk management control system within Birmingham City Council, Management Accounting Research, vol. 20, no. 1, pp. 69-81, DOI 10.1016/j.mar.2008.10.003.
85. Yule, G.U. (1912), On the methods of measuring association between two attributes, Journal of the Royal Statistical Society, vol. 75, no. 6, pp. 579652 , DOI 10.2307/2340126.

86. Zimmerman, J.L. (2001), Conjectures regarding empirical managerial accounting research, Journal of Accounting and Economics, vol. 32, no.1-3, pp. 411-427, DOI 10.1016/s01654101(01)00023-4.

\begin{tabular}{|c|c|c|c|c|c|c|c|c|c|}
\hline \multicolumn{2}{|c|}{ Analysed variables } & \multicolumn{2}{|c|}{$\begin{array}{l}\text { Assessment of extent to } \\
\text { which the information } \\
\text { provided by the MA } \\
\text { department is used in } \\
\text { performing management } \\
\text { tasks }\end{array}$} & \multicolumn{2}{|c|}{$\begin{array}{l}\text { Assessment of the } \\
\text { suitability of certain types of } \\
\text { information provided by the } \\
\text { MAS, in the context of the } \\
\text { management process }\end{array}$} & \multicolumn{2}{|c|}{$\begin{array}{l}\text { Assessment of specific } \\
\text { quality characteristics of } \\
\text { internal reports, prepared } \\
\text { by management } \\
\text { accountants }\end{array}$} & \multicolumn{2}{|c|}{$\begin{array}{l}\text { Assessment of specific } \\
\text { communication channels } \\
\text { for the information } \\
\text { delivered by the MAS }\end{array}$} \\
\hline \multicolumn{2}{|c|}{ Country } & POL & ROM & POL & ROM & POL & ROM & POL & ROM \\
\hline \multirow{3}{*}{$\begin{array}{l}\text { Company } \\
\text { profile }\end{array}$} & $\begin{array}{l}\text { Type of the } \\
\text { company }\end{array}$ & $\begin{array}{l}\text { weak or very } \\
\text { weak } \\
\text { relationship }\end{array}$ & $\begin{array}{l}\text { moderate } \\
\text { relationship } \\
\text { only for } R \& D \\
\text { decisions }\end{array}$ & $\begin{array}{l}\text { weak or very } \\
\text { weak } \\
\text { relationship }\end{array}$ & $\begin{array}{l}\text { weak or very } \\
\text { weak } \\
\text { relationship }\end{array}$ & $\begin{array}{l}\text { weak or very } \\
\text { weak } \\
\text { relationship }\end{array}$ & $\begin{array}{l}\text { weak or very } \\
\text { weak } \\
\text { relationship }\end{array}$ & $\begin{array}{l}\text { weak or very } \\
\text { weak } \\
\text { relationship }\end{array}$ & $\begin{array}{l}\text { weak or very } \\
\text { weak } \\
\text { relationship }\end{array}$ \\
\hline & $\begin{array}{l}\text { Size of the } \\
\text { company }\end{array}$ & $\begin{array}{l}\text { moderate } \\
\text { relationship } \\
\text { only for budget } \\
\text { preparation }\end{array}$ & $\begin{array}{l}\text { moderate } \\
\text { relationship } \\
\text { only for R\&D } \\
\text { decisions }\end{array}$ & $\begin{array}{l}\text { moderate } \\
\text { relationship } \\
\text { for: actual } \\
\text { financial data, } \\
\text { non-financial } \\
\text { indicators }\end{array}$ & $\begin{array}{l}\text { moderate } \\
\text { relationship only } \\
\text { for actual } \\
\text { financial data }\end{array}$ & $\begin{array}{l}\text { moderate } \\
\text { relationship } \\
\text { only for IT } \\
\text { support }\end{array}$ & $\begin{array}{l}\text { moderate } \\
\text { relationship } \\
\text { only for: } \\
\text { comments in } \\
\text { reports }\end{array}$ & $\begin{array}{l}\text { weak or very } \\
\text { weak } \\
\text { relationship }\end{array}$ & $\begin{array}{l}\text { moderate } \\
\text { relationship } \\
\text { for: printed } \\
\text { version of } \\
\text { reports, } \\
\text { mobile } \\
\text { applications, } \\
\text { online } \\
\text { reporting } \\
\end{array}$ \\
\hline & $\begin{array}{l}\text { Origin of the } \\
\text { capital }\end{array}$ & $\begin{array}{l}\text { moderate } \\
\text { relationship } \\
\text { only for budget } \\
\text { preparation }\end{array}$ & $\begin{array}{l}\text { moderate } \\
\text { relationship } \\
\text { only for } R \& D \\
\text { decisions }\end{array}$ & $\begin{array}{l}\text { moderate } \\
\text { relationship } \\
\text { only for } \\
\text { financial } \\
\text { indicators }\end{array}$ & $\begin{array}{l}\text { moderate } \\
\text { relationship for: } \\
\text { financial results } \\
\text { and indicators } \\
\text { (stronger } \\
\text { relationship), } \\
\text { variance } \\
\text { analysis, non- } \\
\text { financial } \\
\text { indicators }\end{array}$ & $\begin{array}{l}\text { moderate } \\
\text { relationship } \\
\text { only for } \\
\text { relevance }\end{array}$ & $\begin{array}{l}\text { moderate } \\
\text { relationship } \\
\text { only for degree } \\
\text { of detail }\end{array}$ & $\begin{array}{l}\text { weak or very } \\
\text { weak } \\
\text { relationship }\end{array}$ & \begin{tabular}{|l} 
moderate \\
relationship \\
only for online \\
reporting
\end{tabular} \\
\hline \multirow{3}{*}{$\begin{array}{c}\text { Manager } \\
\text { profile }\end{array}$} & $\begin{array}{l}\text { Professional } \\
\text { experience }\end{array}$ & $\begin{array}{l}\text { weak or very } \\
\text { weak } \\
\text { relationship }\end{array}$ & $\begin{array}{l}\text { weak or very } \\
\text { weak } \\
\text { relationship }\end{array}$ & $\begin{array}{l}\text { moderate } \\
\text { relationship } \\
\text { only for } \\
\text { revenues }\end{array}$ & $\begin{array}{l}\text { moderate } \\
\text { relationship for: } \\
\text { financial } \\
\text { indicators, } \\
\text { variance } \\
\text { analysis }\end{array}$ & $\begin{array}{l}\text { moderate } \\
\text { relationship } \\
\text { only for } \\
\text { reference to } \\
\text { the future }\end{array}$ & $\begin{array}{l}\text { moderate } \\
\text { relationship } \\
\text { only for clarity }\end{array}$ & $\begin{array}{l}\text { weak or very } \\
\text { weak } \\
\text { relationship }\end{array}$ & $\begin{array}{l}\text { moderate } \\
\text { relationship } \\
\text { only for } \\
\text { printed } \\
\text { version of } \\
\text { reports }\end{array}$ \\
\hline & Education & $\begin{array}{l}\text { weak or very } \\
\text { weak } \\
\text { relationship }\end{array}$ & $\begin{array}{l}\text { weak or very } \\
\text { weak } \\
\text { relationship }\end{array}$ & $\begin{array}{l}\text { weak or very } \\
\text { weak } \\
\text { relationship }\end{array}$ & $\begin{array}{l}\text { weak or very } \\
\text { weak } \\
\text { relationship }\end{array}$ & $\begin{array}{l}\text { weak or very } \\
\text { weak } \\
\text { relationship }\end{array}$ & $\begin{array}{l}\text { moderate } \\
\text { relationship for: } \\
\text { completeness, } \\
\text { comparability }\end{array}$ & $\begin{array}{l}\text { weak or very } \\
\text { weak } \\
\text { relationship }\end{array}$ & $\begin{array}{l}\text { weak or very } \\
\text { weak } \\
\text { relationship }\end{array}$ \\
\hline & $\begin{array}{l}\text { Managed } \\
\text { department }\end{array}$ & $\begin{array}{l}\text { moderate } \\
\text { relationship } \\
\text { for: budget } \\
\text { preparation } \\
\text { (stronger } \\
\text { relationship), } \\
\text { investment } \\
\text { decisions }\end{array}$ & $\begin{array}{l}\text { moderate } \\
\text { relationship } \\
\text { for: budget } \\
\text { preparation, } \\
\text { department } \\
\text { management, } \\
\text { R\&D } \\
\text { decisions, }\end{array}$ & $\begin{array}{l}\text { weak or very } \\
\text { weak } \\
\text { relationship }\end{array}$ & $\begin{array}{l}\text { moderate } \\
\text { relationship for: } \\
\text { costs, results, } \\
\text { financial } \\
\text { indicators, } \\
\text { actual financial } \\
\text { data (stronger } \\
\text { relationship), }\end{array}$ & $\begin{array}{l}\text { weak or very } \\
\text { weak } \\
\text { relationship }\end{array}$ & $\begin{array}{l}\text { moderate } \\
\text { relationship for: } \\
\text { graphical } \\
\text { presentation, IT } \\
\text { support }\end{array}$ & $\begin{array}{l}\text { weak or very } \\
\text { weak } \\
\text { relationship }\end{array}$ & $\begin{array}{l}\text { moderate } \\
\text { relationship } \\
\text { only for } \\
\text { printed } \\
\text { version of } \\
\text { reports }\end{array}$ \\
\hline
\end{tabular}




\begin{tabular}{|c|c|c|c|c|c|c|c|c|c|}
\hline \multicolumn{2}{|c|}{ Analysed variables } & \multicolumn{2}{|c|}{$\begin{array}{l}\text { Assessment of extent to } \\
\text { which the information } \\
\text { provided by the MA } \\
\text { department is used in } \\
\text { performing management } \\
\text { tasks }\end{array}$} & \multicolumn{2}{|c|}{$\begin{array}{l}\text { Assessment of the } \\
\text { suitability of certain types of } \\
\text { information provided by the } \\
\text { MAS, in the context of the } \\
\text { management process }\end{array}$} & \multicolumn{2}{|c|}{$\begin{array}{l}\text { Assessment of specific } \\
\text { quality characteristics of } \\
\text { internal reports, prepared } \\
\text { by management } \\
\text { accountants }\end{array}$} & \multicolumn{2}{|c|}{$\begin{array}{l}\text { Assessment of specific } \\
\text { communication channels } \\
\text { for the information } \\
\text { delivered by the MAS }\end{array}$} \\
\hline \multicolumn{2}{|c|}{ Country } & POL & ROM & POL & ROM & POL & ROM & POL & ROM \\
\hline & & & $\begin{array}{l}\text { cost control } \\
\text { and } \\
\text { assessment } \\
\text { of internal } \\
\text { projects } \\
\end{array}$ & & $\begin{array}{l}\text { planned } \\
\text { financial data }\end{array}$ & & & & \\
\hline \multirow{3}{*}{$\begin{array}{l}\text { Operations } \\
\text { of the MA } \\
\text { department }\end{array}$} & $\begin{array}{l}\text { Organisation } \\
\text { of MA } \\
\text { department }\end{array}$ & $\begin{array}{l}\text { weak or very } \\
\text { weak } \\
\text { relationship }\end{array}$ & $\begin{array}{l}\text { weak or } \\
\text { relationship }\end{array}$ & \begin{tabular}{|l|} 
moderate \\
relationship \\
only for \\
variations \\
analysis \\
\end{tabular} & $\begin{array}{l}\text { weak or very } \\
\text { weak } \\
\text { relationship }\end{array}$ & $\begin{array}{l}\text { weak or very } \\
\text { weak } \\
\text { relationship }\end{array}$ & $\begin{array}{l}\text { weak or very } \\
\text { weak } \\
\text { relationship }\end{array}$ & $\begin{array}{l}\text { weak or very } \\
\text { weak } \\
\text { relationship }\end{array}$ & $\begin{array}{l}\text { weak or very } \\
\text { weak } \\
\text { relationship }\end{array}$ \\
\hline & $\begin{array}{l}\text { Frequency of } \\
\text { reporting }\end{array}$ & \begin{tabular}{|l|} 
moderate \\
relationship \\
only for \\
investment \\
decisions
\end{tabular} & $\begin{array}{l}\text { moderate } \\
\text { relationship } \\
\text { for: long-term } \\
\text { planning, cost } \\
\text { control }\end{array}$ & $\begin{array}{l}\text { weak or very } \\
\text { weak } \\
\text { relationship }\end{array}$ & \begin{tabular}{|l|} 
moderate \\
relationship only \\
for costs
\end{tabular} & $\begin{array}{l}\text { moderate } \\
\text { relationship } \\
\text { only for IT } \\
\text { support }\end{array}$ & $\begin{array}{l}\text { weak or very } \\
\text { weak } \\
\text { relationship }\end{array}$ & $\begin{array}{l}\text { weak or very } \\
\text { weak } \\
\text { relationship }\end{array}$ & $\begin{array}{l}\text { moderate } \\
\text { relationship } \\
\text { only for } \\
\text { mobile } \\
\text { reporting }\end{array}$ \\
\hline & $\begin{array}{l}\text { Frequency of } \\
\text { meetings } \\
\text { between } \\
\text { managers } \\
\text { and } \\
\text { management } \\
\text { accountants }\end{array}$ & $\begin{array}{l}\text { moderate } \\
\text { relationship } \\
\text { for: strategy } \\
\text { implementatio } \\
\text { n, budget } \\
\text { preparation, } \\
\text { performance } \\
\text { measurement, } \\
\text { making short- } \\
\text { term decisions }\end{array}$ & $\begin{array}{l}\text { moderate } \\
\text { relationship } \\
\text { for: strategy } \\
\text { implementatio } \\
\text { n, } \\
\text { performance } \\
\text { measurement }\end{array}$ & $\begin{array}{l}\text { moderate } \\
\text { relationship } \\
\text { for: revenues, } \\
\text { financial } \\
\text { indicators, } \\
\text { variance } \\
\text { analysis }\end{array}$ & \begin{tabular}{|l} 
moderate \\
relationship for: \\
financial results \\
and indicators, \\
variance \\
analysis, \\
planned \\
financial data
\end{tabular} & $\begin{array}{l}\text { weak or very } \\
\text { weak } \\
\text { relationship }\end{array}$ & \begin{tabular}{|l|} 
moderate \\
relationship \\
only for: clarity, \\
comprehensibili \\
ty, degree of \\
detail and \\
references to \\
the future
\end{tabular} & $\begin{array}{l}\text { weak or very } \\
\text { weak } \\
\text { relationship }\end{array}$ & $\begin{array}{l}\text { weak or very } \\
\text { weak } \\
\text { relationship }\end{array}$ \\
\hline
\end{tabular}

Source: Authors' own elaboration 